\title{
Risk-based Pricing of Interest Rates in Household Loan Markets
}

\author{
Wendy Edelberg*
}

December 5, 2003

\begin{abstract}
Focusing on observable default risk's role in loan terms and the subsequent consequences for household behavior, this paper shows that lenders increasingly used risk-based pricing of interest rates in consumer loan markets during the mid-1990s. It tests three resulting predictions. First, the premium paid per unit of risk should have increased over this period. Second, debt levels should react accordingly. Third, fewer high-risk households should be denied credit, further contributing to the interest rate spread between the highest- and lowest-risk borrowers. For those obtaining loans, the premium paid per unit of risk did indeed become significantly larger over this time period. For example, given a 0.01 increase in the probability of bankruptcy, the corresponding interest rate increase tripled for first mortgages, doubled for automobile loans and rose nearly six times for second mortgages. Additionally, changes in borrowing levels and debt access reflected these new pricing practices, particularly for secured debt. Borrowing increased most for the low-risk households who saw their relative borrowing costs fall. Furthermore, while credit access increased for very high-risk households, the increases in their risk premiums implied that their borrowing as a whole either rose less or, sometimes, fell.
\end{abstract}

\footnotetext{
*Federal Reserve Board, email:Wendy.M.Edelberg@frb.gov. The views presented are solely those of the author and do not necessarily represent those of the Federal Reserve Board or its staff. I would like to thank Pierre-Andre Chiappori, Lars Hansen, Erik Hurst and Annette Vissing-Jorgensen, for their direction and advice. I also would like to thank the University of Chicago, the National Science Foundation and the Social Science Research Council for their financial support. Of course, all errors are my own.
} 


\section{Introduction}

The credit industry literature suggests that by the early 1980s conventional lenders were using credit scores and the like to automate underwriting standards, but as late as the early 1990s they simply posted one "house rate" for each loan type and rejected most high-risk borrowers (Johnson, (1992)). As data storage costs subsequently fell and underwriting technology improved, however, lenders began to use estimates of default risk to assess different interest rates for individual loans. This paper examines both the extent and consequences of the increased use of risk-based pricing of interest rates in consumer loan markets during the mid-1990s. Put briefly, risk-based pricing is the practice of lenders charging each borrower a specific interest rate based on credit risk rather than charging one single house rate.

The paper tests three predictions based on these changes. First, the premium paid per unit of risk should increase. Second, debt levels should react accordingly. Third, fewer very high-risk households should be denied credit, further contributing to an increase in the spread between the interest rates paid by highest and lowest risk borrowers. In order to isolate the potential effects of risk-based pricing, I empirically model interest rate determination for a broad spectrum of consumer loans, allowing default risk to play a key role. I estimate the actual extent of default risk's role in interest rate setting by using two sources of risk: the risk of being late on payments and the risk of bankruptcy.

On the whole, the results are in keeping with the predictions. For those obtaining loans, the premium paid per unit of risk became significantly larger over this time period, with the difference between high- and low-risk borrowers' interest rates at least nearly doubling for secured loans and increasing for most unsecured loans, as well. Moreover, changes in borrowing levels and access to debt reflected these new pricing practices, particularly for secured debt. While the overall lower levels of interest rates generally boosted borrowing in the late 1990s, the demand for credit increased most for low-risk households who saw lower relative borrowing costs. In addition, these changes in pricing practices led to increased credit access for very highrisk households (again, particularly for secured debt), but the increase in the risk premium faced by these households also caused their average borrowing levels to either rise less or, for some loan types, to fall. In the end, changes in risk-based pricing may account for between $25 \%$ and 
$75 \%$ of increases in consumer debt levels for certain types of secured loans. And, these changes may more than account for the increased use of secured consumer debt by the highest risk groups.

\section{Risk-Based Pricing in Consumer Credit Markets}

Although conventional lenders began to use credit scores to automate underwriting standards in the early 1980s, for many years after they continued to post one house rate for each loan type and reject very high-risk borrowers (Johnson, (1992)). During the 1990s, however, significant improvements in underwriting models and substantial reductions in data storage costs decreased the costs of risk-based pricing (Bostic, (2002)). For example, while data storage costs fell by a factor of nearly 7 from 1985 to 1990, they fell by a factor of over 21 from 1990 to 1995 (Dahlin (2000)). ${ }^{1}$

Certain changes in consumer credit industry practices spurred investment in developing new underwriting models. While the CRA had been on the books since 1977, Canner and Passmore (1997) explain that in 1995, bank regulators began implementing more stringent performance-based measures of a lending institution's compliance. A greater emphasis was placed on lending in lower income neighborhoods and to lower income borrowers, increasing the profitability of developing a technology to lend to higher risk households.

Adding to the pressures on conventional lenders, Fannie Mae - which previously had purchased only low-risk loans and essentially did not vary any of the financial terms with the riskiness of the loan - introduced a new and improved automated underwriting system in 1995 and began to accept higher risk loans. Subsequently, Fannie Mae began to vary the some of the terms with the loan's level of risk. In 1996 both Fannie Mae and Freddie Mac "made it clear that lenders who wanted to sell mortgage loans [to them] would be well-advised to include a credit bureau score as part of the loan package (McCorkell, (2002))."

Given these changes, in the mid 1990s lenders could, and did, begin to issue higher risk mortgages (Freeman and Hamilton, (2002)). The technology of risk-based pricing made its way

\footnotetext{
${ }^{1}$ In addition, Peter McCorkell suggests insufficient data on defaults (from a lack of 'bad loans') made riskbased pricing difficult prior to 1995. Furthermore, he points out that until the late 1980s, mortgage lenders simply relied on their constantly appreciating collateral to moderate the costs of default rather than investing in models of credit risk (McCorkell, (2002)).
} 
from mortgage loans into other loans types, such as second mortgages, automobile loans and credit card loans. Given the empirical results in this paper, it appears loans easily securitized have been affected the most, suggesting that secondary loan markets have played a role in promoting risk-based pricing.

\section{Literature Review}

In the 1960's, a number of studies considered the inequality of the costs of credit across classes, showing the extent - more or less - to which interest rates varied by default risk. In general, they showed that poorer households paid more for credit (for example, Caplovitz, (1967), Consumer Credit and the Low Income Consumer, (1969), and Aaker and Day, (1971)). Donald Hester presented one of the first references to a loan offer function: $F(t ; u, v)=0$, where $t$ are the loan terms, such as interest rate and loan size, and $u$ and $v$ are the bank and borrower attributes, respectively (Hester, (1967)). Much of the more recent work on costs of borrowing focuses on the related topic of liquidity constrained households - in order words testing whether some households have infinite borrowing costs. Some relevant examples, such as Zeldes (1989), Jappelli (1990), Runkle (1991) and Duca and Rosenthal (1993), test for the presence of liquidity constraints.

This paper should be thought of as a counterpart to the emerging theoretical literature modeling the relationship between heterogeneous terms of borrowing and default risk. Araujo and Pascoa (1999) present a general equilibrium model relating greater default risk to higher interest rates, but this model does not allow for straightforward empirical tests. Han studies discrimination in credit markets on the accept/reject margin. In the process, he introduces a loan offer function in a competitive loan industry, where loan repayments, given a fixed loan size, increase in credit risk (Han, (1998)). Geanakoplos has written and co-written a number of papers showing the effect of default risk on loan terms in general equilibrium (some examples are Geanakoplos (2002) and Dubey et al (2003)). Chatterjee et al (2002) presents a fully specified model of unsecured credit with an endogenous risk of bankruptcy that is able to match a number of facts in the household loan market.

On the empirical side, Gropp et al (1997) and Berkowitz and Hynes (1998) analyze the effect of bankruptcy exemption levels on loan terms, accessibility to debt and debt levels. A few 
recent papers begin to tackle the issue of changes in borrowing costs due to technological changes in consumer loan markets. McCorkell shows that, overall, the use of credit scoring has made judging loan applications more consistent and unbiased across the population and has helped households traditionally underserved by the credit industry (McCorkell, (2002)). Kathleen Johnson reviews the impact of increases in loan securitization on consumer loan markets and determines that it has decreased costs of borrowing on average (Johnson, (2002)).

\section{Data}

Most of the data used in this paper are from the Surveys of Consumer Finances (SCFs) that were conducted every three years from 1983 to $1998 .^{2}$ Across all years there are a total of 19,756 households. The SCF contains data on a broad array of collateralized and noncollateralized loans and their interest rates. The loans considered in this paper are first and second mortgages, automobile loans, general consumer loans, credit card loans and education loans. ${ }^{3}$ All loans are active in the month of the survey, including credit card loans; credit card balances are only defined as loans when the household is carrying the balance long enough to pay interest on it. ${ }^{4}$ In addition, if households have multiple loans in a category, the highest interest rate is used in the analysis, and the dollar amounts relevant for the multiple loans are summed. This interest rate can then be thought of as the marginal rate at which a household could borrow one additional dollar using that particular kind of loan. The SCF also contains data on a broad array of household characteristics, both demographic and financial. ${ }^{5}$ All dollar amounts are deflated to 1998 dollars using the consumer price index.

Table 1 shows the total observations across the five years of data for the various loan categories that were considered, anticipating some of the differences in the results' robustness. In

${ }^{2}$ The 1986 survey used a different sampling methodology and thus is excluded from the analysis.

${ }^{3}$ General consumer loans include loans for household appliances, medical bills, loans from individuals and others. When these loans are collateralized, the collateral is less secure that an automobile or a house. Generally, the borrower keeps possession inside the house (making seizure difficult) and value of the asset is quite variable.

${ }^{4}$ One drawback that Gross and Souleles (2001) points out in the SCF is that respondents underreport credit card debt. This could pose a problem to the credit card results if underreporting is significantly correlated with risk, and this correlation changes over time.

${ }^{5}$ Unfortunately, the SCF does not contain certain data that would be helpful in evaluating loan terms. For example, post-1983, the public dataset does not report the respondent's state, only their very broad region of the country. Additionally, the data on mortgages does not include any prepayment information or points paid. 
addition, the mean and standard deviation of the interest rate for 1998 loan originations years are reported for each loan. ${ }^{6}$ Overall, the results are just as one might expect. ${ }^{7}$ First mortgages have the lowest interest rates while credit card rates are the highest, and other consumer loan rates are the second highest. ${ }^{8}$

Because the SCF surveys before 1998 do not report whether a household has declared bankruptcy - certainly an important indicator of default risk needed to understand interest rate determination - the Michigan Panel Study of Income Dynamics (PSID) is also employed. The PSID is a longitudinal data set of US households dating back to 1968. In 1996, the PSID asked households if they had ever filed for bankruptcy in the past, and if they had, what year(s). A model of bankruptcy risk is estimated in the PSID and then used to assess bankruptcy risk of SCF households.

The PSID includes information on the level of unsecured debt and the value of nonhousing wealth in only 1984, 1989 and 1994. In order to include net worth and debt in the analysis, only these three years of data are included. Aside from bankruptcies, every variable from the PSID used in this paper has a close counterpart in the SCF. The total number of distinct households across the years of data with bankruptcy statistics is 7,665. Among these households, the total number of bankruptcies across all years prior to 1996 is 502 . This reflects a slightly lower rate of occurrence of bankruptcy than that observed in the US population, as the PSID underestimates the frequency of bankruptcy. ${ }^{9}$

${ }^{6}$ Sampling weights are used in measures of first and second moments using the SCF data. Deaton (1997) makes a convincing argument that weights should not be included in models when parameters do not vary across the population - which they do not in the empirical models.

${ }^{7}$ Interestingly, rates on education loans are remarkably low with a standard deviation more in line with the collateralized loans. This possibly reflects the government's involvement in this market or that this loan - more than other non-collateralized loans - is dedicated to a productive purpose. Additionally, government-backed education loans cannot be discharged in bankruptcy proceedings.

${ }^{8}$ I get the same qualitative results if I do not condition on the year of loan issuance and instead look at moments for the 1998 survey year.

${ }^{9}$ For example, the filing rate in the PSID was $0.15 \%$ of the total population in 1984 and $0.59 \%$ in 1995 . To compare these rates to national data, the filing rate was $0.33 \%$ in 1984 and $0.88 \%$ in 1995 (Fay et al (1998)). Andreas Lehnert points out that national statistics include repeat chapter 13 filings separately while households may consider these as one filing. Technical reasons commonly lead to multiple Chapter 13 filings. Additionally, the lowincome subsample is included in the data since this population is of interest in studying consumer lending. If it were removed, bankruptcy rates might match the total population more closely. 


\section{Empirical Analysis}

\section{General setup}

The primary goal of this empirical analysis is to estimate the role default risk plays in interest rate determination and see if that role has changed over time. To simplify the analysis, assume that a household requests a certain loan amount, $A$, and offers enough collateral to ensure a recovery rate, $l$, of the loan balance. These loan attributes are then simply inputs into an interest rate determination model. ${ }^{10}$ As a function of these attributes, as well as the lender's discount rate, $o$, any fixed costs, $f$, and of course the borrower's default risk, $d$, the lender then offers an interest rate. The household accepts the loan if the offered interest rate is lower than the household's reservation interest rate, $R$, given the loan attributes and the household's characteristics, $P .^{11}$ Because the SCF only reports interest rate data for households who successfully secure loans, I must account for selection bias. Without observing the reservation interest rate, we can still infer that it is higher than or equal to the offered interest rate for those consumers who have positive loan balances. To formalize:

$$
\begin{gathered}
R_{i}\left(A, l, P_{i}\right)-I_{i}\left(A, l, d_{i}, o, f\right)=H_{i} \beta+u_{i} \\
\operatorname{Prob}\left(R_{i}-I_{i}>0\right)=\Phi\left(H_{i} \beta\right)
\end{gathered}
$$

$R_{i}\left(A, l, P_{i}\right)$ is the reservation interest rate, and $I_{i}\left(A, l, d_{i}, o, f\right)$ is the interest rate offered by the lender. $H_{i}$, a vector of characteristics, helps predict whether the loan is observed for household $i$. The interest rate and reservation rate functions, $I_{i}$ and $R_{i}$, are subscripted $i$ to allow for an idiosyncratic individual specific shock, $\varepsilon_{i}$.

\footnotetext{
${ }^{10}$ As the objective of this approach is to measure the influence of borrower's observable risk, issues of asymmetric information are not considered. However, strategic default may play an indirect role if lender's use observable borrower's characteristics to predict the likelihood of strategic default which is incorporated into overall default risk. Due to data limitations, prepayment risk is not considered.

${ }^{11}$ Maturity does not generally vary meaningfully within a loan type and was often found to have no real significant effect on interest rates, so it is excluded from the model. For example, over one-half of mortgages have 30 year maturities, and nearly $60 \%$ of automobile loans have maturities between four and five years.
} 


$$
I_{i}\left(A, l, d_{i}, o, f\right)=\mathrm{X}_{i} \gamma+\varepsilon_{i}, \text { observed when } R_{i}-I_{i}>0
$$

Here, $\mathrm{X}_{i}$ is a vector of characteristics that help predict loan interest rates, $I . \mathrm{X}$ includes direct measures or proxies, where necessary, for $A, l, d, o$ and $f$. Note that this model essentially does not allow for a rejection by the lender. However, we can consider a loan rejected any time $R_{i}-I_{i} \leq 0 .^{12}$

$H$ should contain variables that determine whether or not a household carries a particular loan. As a result, both supply and demand variables should be included. On the supply side, $H$ includes variables that help predict when a firm may deny a loan. For example, default risk should play a role here. Without taking a definite stand on the nature of this role, $H$ includes second-order polynomials of default risk. To account for demand, other financial and demographic characteristics, $P_{i}$, that might predict whether a family holds a loan are included: an age polynomial, marriage status, the number of children, whether the family has a checking account, education, log of income, net worth, level of assets, and variables that reflect borrowing attitudes (which are discussed in detail below). Race is also included in $H$ for two reasons. First, it is possible that racial status reflects differences in preferences and attitudes towards borrowing. Second, while this is not the focus of the paper, lenders may discriminate in access to loan markets (see Edelberg (2002)).

If markets are competitive, interest rates should only vary for reasons captured in $I_{i}(A, l, d, o, f)$; lenders should not be able to exploit variations in household demand. For example, if an agent's higher demand for debt induces him to carry many loans, he should be a higher risk than an agent should be with a low demand for debt, and he should receive a higher interest rate only because of his higher default risk.

I must find at least one variable in $H$ that is not in $\mathrm{X}$, so as to not depend on the functional form to identify the model. Certainly, exogenous observable characteristics such as age, education, wealth and income should be included in both in some way, even if they only influence interest rates through their effect on households' default risk. On the other hand, the

\footnotetext{
${ }^{12}$ For example, if a lender at least knows the upper bound for a household's reservation interest rate, it may choose to simply reject a loan rather than offer an interest rate above this upper bound.
} 
SCF solicits information on household's opinions about borrowing that is private to the household and thus cannot be used by the bank in determining an interest rate. For example, households report whether they consider borrowing to be good, bad, or simply okay and whether they believe borrowing is acceptable in certain circumstances - such as for a loss in income or to buy a house or an automobile. These attitudinal responses are included in $H$ and excluded from X.

While a family that reports it is acceptable to borrow for education expenses might be more likely to hold an education loan, these attitudinal variables will contain little information if they reflect each household's loan portfolio precisely. Fortunately, they do not. Table 2 contains a breakdown of the percentage of households that hold certain types of loans and those that report which type of borrowing is acceptable. Though there is clearly a correlation between attitudes and debt holdings, the attitudinal variables do not simply reflect current borrowing habits. For example, only $34 \%$ of those who agree that it is acceptable to hold an automobile loan actually do hold one. Other robustness checks confirm that these attitudinal responses are not simply proxies for variables seen by the lender and not contained in the data sets. ${ }^{13}$

Of the inputs used to construct $I_{i}(A, l, d, o, f)$, some are straightforward to include in a reduced form equation. For example, the discount rate, $o$, which is dependent on the cost of funds, is presumed constant over a year and is captured by year dummies. ${ }^{14}$ In as much as fixed costs, $f$, are recovered through the interest rate, their influence will be seen through the different effects for each loan type of varying the loan amount, $A .{ }^{15}$ For non-collateralized loans, $l$ should

\footnotetext{
${ }^{13}$ In the end, numerous variables are included in $H$ but not in $\mathrm{X}$, so that the demands on the attitudinal variables as appropriate instruments are less than they might be. However, robustness checks were still done. All the significant attitudinal variables from the probits were included in their respective regressions. For example, if an attitudinal variable were significant in the mortgage probit so that it helped to predict which households hold a mortgage, it would then be included in the mortgage interest rate equation. In all cases, a majority of these coefficients in the interest rate regressions were insignificant - in most cases an overwhelming majority.

${ }^{14}$ This should in part reflect the required rate of return to those supplying loanable funds. For example, Ausubel (1991) finds that credit card issuers earned between 3 and 5 times the ordinary banking rate of return from 1983 to 1988. My methodology imposes no specific rate of return on each type of loan, but does take these returns to be the result of competitive markets.

${ }^{15}$ Interest rates on general consumer loans are better predicted by current loan balances rather than original loan amounts. This may be due to the more informal nature of this loan category. For example, these loans may be renegotiated more easily so that current balance is also highly relevant for the terms.
} 
be close to constant within a loan-type (for example, credit card lenders use roughly the same expected recovery ratio for all loans), and its varying effects for different loans will be loaded into the constants. ${ }^{16}$ For collateralized loans, accounting for $l$ in each type of loan is not as straightforward. However, it can generally be assumed that $l$ will be higher for a loan that is $100 \%$ collateralized than for one that is only $50 \%$ collateralized. Although a creditor can seek a lien against a borrower if there is a deficiency after repossession, the deficiency is treated like an unsecured loan. In practice, creditors rarely go after deficiencies and generally recover no more than 5 to $15 \%$ of the deficiency when they do (Winton, (1998)). To keep things simple and yet capture the effect of varying $l$, equity in the relevant loan collateral is included as a predictor of interest rates.

This brings us to estimating default risk, $d$. Although each household's credit score is unavailable, the SCF does contain data on actual delinquencies that can be used to generate a proxy for the score. Households that are late on their payments can be a source of substantial costs to a lender. If a household is late in making payments, a lender may need to flag the account, make contact with the household, perhaps begin to partially write-off the debt, and eventually send (or sell) the loan to a collection agency. The SCF reports whether respondents have been more than sixty days late on a loan payment in the twelve months prior to the survey date. Lenders will generally not have data on these delinquencies when setting interest rates on the loans captured by the SCF at the time of the survey, as most loans considered here are over a year old. A lender's assessment of a household's default risk can be approximated by predicting of the probability of being delinquent on payments in the empirical analysis. ${ }^{17}$

Arguably it might be appropriate to include actual rather than predicted delinquencies. Assuming rational expectations, lenders should get these predictions right on average, and because it is likely that lenders have better financial and demographic data than what are contained in the SCF, lenders may have much better predictions of this form of default risk than

\footnotetext{
${ }^{16}$ The possible complication that $l$ may be in part a function of $d$ - for example, ex ante high-risk people in default may be more difficult to collect from than low-risk people in default - is not considered here.

${ }^{17}$ As will be clear in the empirical analysis, a good bit of the information in late payments is indeed used by lenders in pricing interest rates at loan origination. For every loan considered, average rates paid are higher for those who made late payments versus those who had no late payments, with the differences ranging from a low of 0.2 percentage point for education loans to a high of nearly 2.5 percentage points for automobile loans.
} 
what this empirical analysis can produce. In the end, estimations are conducted using both predicted and actual delinquencies, and large differences are noted, though results are generally robust to either specification.

Of course, being delinquent on payments is only one important source of default risk. Lenders are also concerned with outright bankruptcy. Unfortunately, the SCF before 1998 contains no bankruptcy data. However, the 1996 supplement to the PSID does contain data on whether and when households declared bankruptcy. To obtain predictions of which households are likely to declare bankruptcy in analyzing SCF data, I estimate a model of future bankruptcy in the PSID and then use these coefficients to impute probabilities in the SCF. ${ }^{18}$ The necessary correction of the standard errors is done following the approach in Murphy and Topel (1985).

\section{Bankruptcy}

Bankruptcy is measured as an indicator variable. It takes a value of one if the respondent declared bankruptcy within two years after the three PSID surveys that are used. This structure of the data allows two forms of bankruptcy risk to be estimated with a probit. First, a probability of declaring bankruptcy will be predicted for those households with debt as of the survey date. This conditional bankruptcy probability will be relevant for lenders assessing interest rates for loans, and thus will be included in $X$.

Second, a probability of declaring bankruptcy will be predicted for all households, whether or not they hold debt as of the survey date. A full $14 \%$ of bankruptcies that are declared within two years of the survey date are originated by households with no debt as of the survey date, and thus zero current debt does not imply zero future bankruptcy risk. This unconditional bankruptcy measure reflects the predictive power of certain financial and demographic characteristics aside from debt levels. Because this measure does not include any debt measures, it is included in $H$, the vector of characteristics predicting whether a household holds a certain

\footnotetext{
${ }^{18}$ This method of including predicted bankruptcy rates from the PSID follows from Jappelli, Pischke and Souleles (1998). Jappelli et al need predictions of which households are liquidity constrained in their analysis of PSID data. They estimate the probability of being liquidity constrained in the SCF and then impute probabilities in PSID respondents by using the estimated model and similar characteristics.
} 
loan. Note that households with debt have both a conditional and an unconditional bankruptcy probability, whereas households with no debt have only an unconditional bankruptcy probability.

Quite a bit of research has examined the household characteristics that belong in a bankruptcy model. ${ }^{19}$ Based on this research, chosen characteristics for the conditional bankruptcy risk are as follows: year, a second order polynomial in age, whether a household has a checking account, the natural log of income, whether a household is self employed, home ownership status, whether the ratio of unsecured debt to income is greater than two, net worth (with negative net worth set to zero), non-collateralized debt, whether the family head is unemployed, race, whether the head is a single parent, and an education class variable taking five values. ${ }^{20}$ For the unconditional estimation, measures of debt and home ownership status are removed and asset levels are included. The results are reported in Table 3 and Table 4. For all explanatory variables, the hypothesis that the coefficients changed over time was tested. In the end, the only time interacted coefficients that were kept were those for the variables with coefficients significantly changing over time.

Overall, the coefficients for both the unconditional and conditional estimations are in keeping with what is known about bankruptcy. A few highlights are discussed here. As shown in Gross and Souleles (1999), the year dummies indicate that the probability of bankruptcy has generally increased over time. As the results in Sullivan et at (1989) would predict, an increase in the natural log of income increases the probability of declaring bankruptcy. In other words, an increase in income increases the probability of bankruptcy, but at a decreasing rate. The probability of declaring bankruptcy should increase in the lower regions of income since bankruptcy offers a way to shield income from garnishment. As income increases, however, the advantages of bankruptcy increase, but the need to declare bankruptcy decreases. For similar reasons, being unemployed reduces the chance of bankruptcy by about $0.2 \%$ - without clear-cut prospects of future income, bankruptcy loses some of its appeal.

\footnotetext{
${ }^{19}$ Research used to identify explanatory variables includes Sullivan et al (1989), Johnson (1992), Domowitz and Sartain (1999), Gross and Souleles (1999), Sullivan et al (2000), and Fay et al (2002).

${ }^{20}$ The five values for education are assigned for 'less than high-school,' 'high-school,' 'some college,' 'college degree,' and 'post-college education.'
} 
Home ownership is significant and positive in the conditional estimation, with a decreasing coefficient over time - turning negative by 1994. This follows the hypothesis in Fay et al (2002) that home ownership has an ambiguous effect on bankruptcy probability. Black households have a lower probability of bankruptcy, though the coefficient is only significant in the unconditional estimation; this result may be capturing the common finding in research that Black households are less involved in the formal financial sector. For education, the point estimate suggests that greater education reduces the probability of bankruptcy, though the effect is only significant and large for the conditional estimation. Though we might expect the better educated to maintain more stable finances, bankrupt households often have more education than the average household, reflecting the skills needed to navigate the bankruptcy system. Education may have two offsetting effects (Sullivan et al (2000)).

To impute probabilities of bankruptcy in the SCF data, I carefully matched the explanatory variables from both surveys and calculated the predicted probabilities of bankruptcy with the SCF year dummies set as closely as possible to the PSID wealth survey dates. Predicted bankruptcy rates from both the SCF and PSID samples across all the years of data are summarized in Table 5. The two samples do not give dramatically different pictures of predicted bankruptcy rates, reflecting that both surveys are including roughly the same population in their samples. Note that for the vast majority of the populations, the predicted probability of bankruptcy within the next two years is quite small; the $90^{\text {th }}$ percentile household with debt in the SCF still has only a $2.3 \%$ predicted probability of declaring bankruptcy.

A useful method of organizing households is by riskiness according to their conditional probability of declaring bankruptcy. Table 6 reports the average values for a number of financial and demographic characteristics by quantile, where the first quantile of probabilities is the least risky and the fifth quantile is the most risky. Averages and quantiles are computed across all years of data. For example, the table shows that riskier households tend to be younger, have lower income and net worth, are less likely to have a checking account, and are more likely to be a single parent. 


\section{Late Payments}

Predictions of the late payment indicator from a probit model are based on the same characteristics as those used to predict bankruptcy. Much less research has been done in the area of delinquency than in bankruptcy, but certainly the insights from bankruptcy research should carry over. Also, this has the benefit of making the late payment results directly comparable to those for bankruptcy.

In the case of bankruptcy, I was predicting whether an event occurred for all households in my sample. In contrast, I only have data on whether households with loans were late on payments. To account for this possible selection bias, I use a similar approach as that used to predict loan interest rates; specifically, the attitudinal variables will ensure identification. Again, I include year interaction terms for coefficients that change significantly over time. As one would imagine, being late on payments is a higher probability event than declaring bankruptcy nearly $9 \%$ of the respondents to the SCF have been late. Results of the selection probit are reported in Table 7.

Predicted probabilities of late payments for the entire SCF sample - conditional on holding debt - are reported in Table 8 . Note that the correlation between predicted bankruptcy and late payments is only 0.35 , reflecting the distinct measures of default risk that these two predicted probabilities represent.

\section{Putting it all together}

Estimated probabilities of SCF households delinquencies are notated $g\left(y_{i}, \hat{\theta}_{M}\right)$ where $y_{i}$ are observable characteristics for household $i$, and $\hat{\theta}_{M}$ is the vector of late payment estimation coefficients in the preceding section. Estimated conditional probabilities of bankruptcy for these households are notated $f_{c}\left(z_{i}, \hat{\theta}_{m}\right)$, and unconditional probabilities are $f_{u c}\left(z_{i}, \hat{\theta}_{m}\right)$, where $z_{i}$ only differs from $y_{i}$ with respect to minor differences in the formation of year dummies, and $\hat{\theta}_{m}$ are the coefficients from the PSID bankruptcy estimation in the Bankruptcy section above. Together, $f\left(z, \hat{\theta}_{m}\right)$ and $g\left(y, \hat{\theta}_{M}\right)$ reflect a household's default risk, $d$. 
An estimate of the contribution of both measures of default risk to interest rate variation before and after 1995 is required to test whether or not the nature of pricing risk changed during the mid-1990s. To do this, each measure of default risk enters on its own and interacted with an indicator variable that takes a value of one if the loan was originated 1995 or later, namely $I_{95}$. The effects of other variables besides those measuring default risk are kept constant over the sample. This methodology allows us to easily see if default risk's contribution significantly changed in the mid-1990s.

In the notation of section General Setup above:

$$
\mathrm{X}=\left[x, f_{c}\left(z, \hat{\theta}_{m}\right) I_{95}, f_{c}\left(z, \hat{\theta}_{m}\right), g\left(y, \hat{\theta}_{M}\right) I_{95}, g\left(y, \hat{\theta}_{M}\right)\right] ; H=\left[h, f_{u c}\left(z, \hat{\theta}_{m}\right), f_{u c}\left(z, \hat{\theta}_{m}\right)^{2}\right]
$$

Given the linearity in $I_{i}=\mathrm{X}_{i} \gamma+\varepsilon_{i}$, this approach depends on the assumption that lenders are risk neutral or are diversified enough to behave as if they are risk neutral. As banks only care about expected return, high-risk borrowers are not penalized for their contributions to the portfolio's variance, only the portfolio's expected return. The potential role of the risk aversion of banks in further increasing the rates paid by high-risk borrowers is left to future work.

As predictors of a loan's interest rates, $x$ includes loan origination year dummies, loan amounts, and equity in collateral where relevant. $\mathrm{X}$ contains $k$ variables in all. Note that $H$ only includes unconditional bankruptcy risk as a measure of default risk. Since the delinquency measure is conditional on holding a loan, its inclusion in $H$ would be inappropriate. Predicting the inclusion of the loan in the household's portfolio, $h$ includes survey year dummies, a secondorder polynomial in age, education, log of income, marriage status, number of dependents, net worth, value of assets, whether the household has a checking account, race, and the attitudinal variables discussed in Table 2 .

Risk-based pricing will be evident by how much interest rates change with a 0.01 increase in bankruptcy risk (e.g. changing from a risk of 0.03 to 0.04$).{ }^{21}$ Additionally, as defined below, the default risk premium spread also helps to measure the extent of risk-based pricing:

\footnotetext{
${ }^{21}$ Given linear interest rate functions, the change in the interest rate per a 0.01 increase in risk is constant. If we were to allow for risk aversion among banks, we might we interest rates as an increasing function of risk.
} 


$$
\begin{aligned}
\text { premium spread } & =\left[\gamma_{k-3} f_{c, R}\left(z, \hat{\theta}_{m}\right) I_{95}+\gamma_{k-3} f_{c, R}\left(z, \hat{\theta}_{m}\right)+\gamma_{k-3} g_{R}\left(y, \hat{\theta}_{M}\right) I_{95}+\gamma_{k-3} g_{R}\left(y, \hat{\theta}_{M}\right)\right] \\
- & {\left[\gamma_{k-3} f_{c, L}\left(z, \hat{\theta}_{m}\right) I_{95}+\gamma_{k-3} f_{c, L}\left(z, \hat{\theta}_{m}\right)+\gamma_{k-3} g_{L}\left(y, \hat{\theta}_{M}\right) I_{95}+\gamma_{k-3} g_{L}\left(y, \hat{\theta}_{M}\right)\right] }
\end{aligned}
$$

where $\gamma^{\prime} s$ are the coefficients from the interest rate equation in the selection model estimation. Note that the risk premium is either post- or pre-1995 depending on the value of the indicator function, $I_{95} . R$ and $L$ define averages of $f_{c}\left(z, \hat{\theta}_{m}\right)$ and $g\left(y, \hat{\theta}_{M}\right)$ for high- and low-risk subsets of the entire population. These subsets are calculated by conditional bankruptcy probabilities: the highest- and lowest-risk groups are the $20 \%$ most and least likely to declare bankruptcy, respectively. These groups remain fixed across all risk premium definitions.

\section{Empirical Results}

\section{Evidence of Changing Default Risk Premium Spread}

To some extent, evidence of the increased use of risk-based pricing is evident even without extensive empirical modeling. Table 9 shows that variances in consumer loan interest rates generally increased - often significantly - between 1989 and 1998. By contrast, for the three survey years shown in the table, standard deviations of monthly prime interest rates were similar in 1989 and 1995 and actually decreased between 1995 and 1998. For example, standard deviations of 30-year fixed Treasury bond rates were 0.50, 0.57 and 0.36 in 1989, 1995 and 1998 respectively. Interest rate spreads between high-risk and low-risk households (defined by conditional probabilities of bankruptcy) also are larger post-1995 versus pre-1995. ${ }^{22}$

Turning to the results from the selection models, Figure 1 shows predicted interest rates plotted against conditional bankruptcy risk pre- and post-1995 loan origination dates. For each loan type, interest rates are predicted by the significant measures of default risk and other

${ }^{22}$ As reported in Table 9, the spreads are taken from interest rates averaged for a two-year period in order to have a reasonable number of observations for each risk group. Under the heading 1989 spreads, interest rates are from 1988 and 1989. For 1995, rates are from 1995 and 1996, and for 1998, rates are from 1997 and 1998. Standard deviations for these years are again similar for monthly interest rates, though in this case prime rates are more variable in 1997 to 1998 then in the prior years. These raw variances and spreads should certainly be interpreted with care since besides loan origination year much is not controlled for. However, first mortgages are limited to 30year fixed-rate mortgages, since changes in raw variances in particular are otherwise difficult to assess. Note that credit card rates are unavailable for 1989, so in the place of 1989, 1983 data are used. 
significant variables are set to their mean values for the entire sample period. The effects of year dummies pre- and post-1995 are averaged so that the predicted zero default interest rate reflects the average discount rate over the period in question. $90 \%$ confidence bands are also reported.

Note that in almost all cases the slopes are steeper in the post-1995 period, indicating that the default risk premium increased. The only exception is other consumer loans, which saw no change over time. In the cases of the other two unsecured loans, credit card and education loans, the pre-1995 line is flat, suggesting that there was no significant default risk premium in this period.

The increasing steepness of the slopes can be summarized by measuring how much interest rates change with an increase of 0.01 in bankruptcy risk. This change more than doubles for first mortgages, going from 0.16 to 0.38 basis points. ${ }^{23,24}$ The change is up nearly five times for second mortgages and more than doubles for automobile loans. As is clear from the figure, there is no change in the slope of the interest rate curve for general consumer loans. Credit card and education loans go from zero slopes to changes in interest rates of 0.48 and 0.30 respectively.

Another way to summarize the information in these graphs is to look at the default risk premium spreads as defined in the previous section. Table 10 shows these for pre-1995 and post1995. For the three types of secured loans, spreads at least nearly double over the sample, with the difference in the spreads significant at the $95 \%$ confidence level in each case. The results are mixed for unsecured loans. The spread is positive but unchanged over the sample for general

\footnotetext{
${ }^{23}$ A number of mortgage characteristics are not considered here. The inclusion of maturity, fixed versus flexible interest rates or FHA loan guarantees does not significantly alter the basic default risk premium spread results, and were excluded to simplify the empirical results and discussion.

${ }^{24}$ While mortgage refinancing was common post-1995 as interest rates fell, this should not falsely produce results of an increase in risk-based pricing. The data is constructed so that borrowers are only compared if their loans were originated in the same year. The default risk premium spread will not increase solely because some loans are a result of refinancing. On the other hand, refinancing booms may mean that older loans are more heavily weighted to those who received bad shocks and would not qualify for new low rates. While this may lead to a lower raw dispersion in interest rates pre-1995 (i.e. if old loans are only held by high-risk households), it will not lead to less dispersion as a function of risk. Additionally, the increase in the mortgage rate default risk premium spreads is not simply due to the addition of a subprime market such that there is little spread within the prime and subprime markets. Rather than a bimodal distribution that this would give rise to, we continue to see a rather smooth bellshaped distribution of mortgage interest rates post-1995. For example, $50 \%$ of the borrowers have rates between $7 \%$ and $8.5 \%, 20 \%$ are between $6 \%$ and $7 \%$ and $20 \%$ are between $8 \%$ and $9 \%$.
} 
consumer loans, positive and statistically significant for credit card loans only post-1995, and is not statistically significant for education loans before or after $1995 .{ }^{25}$

These results are quite robust. Premium spreads calculated from the alternative methodologies are reported in Table 11. Coefficients from the regression portion of these selection models are reported in Table $12 .{ }^{26}$ As mentioned in section Late Payments, an argument can be made for using actual late payments rather than predicted late payments in the interest rate equation estimation. Overall coefficients' values and significance for the unchanged variables are stable. Default risk spreads computed from these coefficients reflect this. While spreads are generally smaller than in the base model, over time they still increase significantly for both mortgage types - more than doubling - as well as for credit card loans. As in the base model, spreads for general consumer loans are unchanged, and education loans still have no significant spread both before and after 1995.

Table 12 also shows the results from using 1996 as the cutoff year rather than 1995. In the case of credit card loans, 1998 is used since there is no credit card data in between survey dates. Secured loan spreads are virtually unchanged and again at least nearly double over time. The results for general consumer loans and education loans show no change. Credit card loans show a spread both before and after the cutoff year, with the spread doubling over time. ${ }^{27}$

\footnotetext{
${ }^{25}$ Note that these premium spreads would not necessarily be observed if we instead looked at the actual population of those using certain types of loan pre- and post-1995. Here, the spreads are calculated using fixed risk classes - essentially giving us a way to summarize the coefficients on default risk in useful economic terms. We could also look at spreads for the population's actual borrowing in each time period, but this would make changes in pricing practices harder to isolate.

${ }^{26}$ The full results of the probit portion of the selection models are available from the author. Overall, the explanatory variables predict a loan's inclusion in a family's portfolio, just as one would expect. However, since variables may be significant for both supply and demand reasons, precise interpretation of the coefficients is difficult. For example, across all loan types aside from education loans, we see the usual life cycle effect with the exception of young households having a lower incidence of debt. This exception is likely due not to demand, but instead to liquidity constraints resulting from lack of credit history.

${ }^{27}$ For credit card loans, one could argue that the model should exclude 1983 data. State usury laws that capped interest rates were rendered ineffective by the Supreme Court Marquette decision in 1978. These laws had the greatest effect on credit card loan rates, as most other rates were under the cap. Arguably, the credit card issuers had not entirely adapted to the decision by 1983 as many companies reacted to it by moving their operations out of state. As evidence of this, the cap in most states was near 18\%, and, in 1983, $63 \%$ of credit card loan interest rates fell between $17 \%$ and $19 \%$. In contrast, in 1995, the highest frequency 2 percent window was between $18 \%$ and $20 \%$, and only $25 \%$ of interest rates fell in this window. Without using 1983, we are left with 1995 and 1998 data. The premium in 1995 is 0.70 , and it significantly rises in 1998 to 1.24 .
} 
Finally, results from models using only conditional bankruptcy and delinquency predictions in turn are reported. Here we see that while the models generally reflect the base model's results, there is value-added from using both measures of default risk. With no conditional bankruptcy included, spreads are roughly unchanged for secured loans, though they are smaller across the board. For unsecured loans, the credit card loan interest rate spread, and now the education loan spread, is significant post-1995. With no predicted late payment measure included, only the first mortgage spread is truly consistent with the base model. Second mortgages work well post-1995, but pre-1995 there is no significant spread. On the other hand, automobiles show no significant change from the pre-1995 spreads, and credit card spread are significantly negative pre-1995. Finally, other consumer loans and education loans have no significant spread at any time.

Across nearly all of the models, the results for secured loans fit well into the hypothesis that lenders increased their use of risk-based pricing after 1995. For unsecured loans, credit card loans are the most robustly consistent with the hypothesis. Interestingly, of the three noncollateralized loan types, credit card loans have the highest incidence of loan securitization. As mentioned in the section Risk-based Pricing in Consumer Loan Markets, the secondary market for loans may motivate risk-based pricing. The absence of evidence of the use of risk-based pricing for other unsecured loans may indicate that lenders have yet to feel the pressures that led to default risk-based pricing in these non-securitized markets.

In addition, costs of default may have decreased over time for some loan types. Winton (1998) discusses how lenders have become more aggressive in obtaining a greater portion of the money owed them before the borrower reaches bankruptcy proceedings. For instance, credit card companies are believed to keep careful track of borrowers in danger of declaring bankruptcy; before the loans are discharged in court, these lenders wage a campaign of telephone calls and letter writing demanding partial payment.

Another reason may be that late fees have risen for unsecured loans, lowering the costs associated with default and impending default. For example, $20 \%$ of profits now come from fees (Sullivan et al (2000) and Manning (2000)). If these efforts were broadly based across unsecured loans, costs of default would fall, and the result should be, then, that the default premium on 
interest rates should fall. Since we see the premium increase for credit card loans, it may be that there are countervailing effects in this market. Perhaps, the need to price risk carefully prevails for credit card loans - due in part to the pressures from secondary loan markets, and these counteracting effects dominate for the other unsecured loans.

\section{Implications for Borrowing}

If lenders declined to charge very high-risk households sufficiently high interest rates prior to the increased use of default risk-based pricing, lending to this group may have proved relatively unprofitable. As Bostic points out, without risk-based pricing, very high-risk people may have been rationed out of the market, rather than be charged high premiums (Bostic, (2002)). With the change in pricing, these very high-risk borrowers should be assessed suitable premiums rather than be denied. Indeed, Yezer states that even lenders who once dealt exclusively with low-risk groups will lend to a much broader range of borrowers with risk-based pricing (Yezer, (2002)). If the offered interest rates are not above the potential borrower's reservation interest rate, we should see use of the various types of consumer debt increase among very high-risk households.

To some extent, this effect is evident in the raw data. While the average income of survey respondents went up $\$ 6,800$ pre-1995 versus post-1995, the average income of those with debt went up only $\$ 5,600$ over the same time periods. Similarly, average education went up about one-half year overall, while the education of those with debt holdings went up a little over onethird year.

Changes in borrowing levels should also have occurred. Prior to the expanded use of riskbased pricing in the mid-1990s, low-risk borrowers were essentially paying relatively higher rates than were appropriate, and high-risk borrowers were paying lower rates. As premiums adjusted to better reflect risk, the spread between premiums for higher risk people and lower risk people increased. Reacting to changing interest rates, borrowing levels among low-risk households should have increased more (or decreased less) than levels for high-risk households. $^{28}$

${ }^{28}$ The change in the overall level of interest rates over time for a particular loan type will have its own effect. For example, interest rates fell across all risk classes for credit card loans, and all risk classes increased their 
Encompassing the debt level and the access to debt effects, the following selection model is estimated using maximum likelihood:

$$
\begin{aligned}
& \ln \left(\hat{B}_{j}\right)=\gamma^{0}+\gamma^{1} \text { oyears }_{95}+\sum_{i=1}^{3} \gamma_{i}^{2}\left(f_{c}\left(z_{j}, \theta_{m}\right)\right){ }^{i}+\sum_{i=1}^{3} \gamma_{i}^{3} \text { oyears }_{95}\left(f_{c}\left(z_{j}, \theta_{m}\right)\right)^{i} \\
& \operatorname{Pr}\left(B_{j}>1\right)=\Phi\left(\begin{array}{l}
\beta^{0}+\beta^{1} \text { years }_{95}+\sum_{i=1}^{3} \beta^{2}{ }_{i}\left(f_{u c}\left(z_{j}, \theta_{m}\right)\right)^{i}+ \\
\sum_{i=1}^{3} \beta_{i}^{3} \text { years }_{95}\left(f_{u c}\left(z_{j}, \theta_{m}\right)\right)^{i}+\text { oborrowing attitudes }
\end{array}\right)
\end{aligned}
$$

Where $B$ is the borrowing dollar level for the various consumer loan types. The year variables are year dummies accounting for changes in the cost of funds. Oyear is the loan origination year and year is the survey year. The third degree polynomial in bankruptcy risk accounts for the possibility that consumer debt use varies with default risk, and the interaction terms measure how this use has changed across risk classes over time.

The results for both the access to debt and debt levels are shown in Figure 2 with $90 \%$ confidence bands. In the first row, the picture is quite clear for first mortgages. The highest-risk households have a higher probability of holding a first mortgage post-1995 versus pre-1995. Additionally, low-risk households are predicted to borrow more post-1995, consistent with a reaction to lower interest rates. The effect lessens as riskiness increases. Changes in interest rates also affect predictions of who holds debt. As interest rates fall for low-risk households, perhaps falling below reservation rates, these families have a higher probability of holding first mortgages. Conversely, as interest rates rise for high-risk groups, these households have a lower probability of holding this debt.

For automobile loans and credit cards loans, the picture for access to debt is similar to that for first mortgages. While the confidence intervals suggest less certainty for these loan types for very high-risk households, at least for credit card loans the post-1995 point estimates fall outside the range of the pre-1995 90\% confidence bands. The predicted debt levels for automobile loans are quite consistent with the hypothesis. Indeed, we see that as a function of

credit card borrowing. However, they fell more for low-risk borrowers. In this case, we would expect borrowing to increase more for low-risk households than high-risk households. 
bankruptcy risk, conditional on holding debt, high-risk households are predicted to hold lower levels of automobile debt post-1995. Given that credit card debt became so much more popular through the 1990s, all credit card borrowers are predicted to increase debt levels.

Equivalent figures for the other debt types are less informative. Second mortgages are unique in that only households with first mortgages hold them, so access to this market is not as a useful a question. Other consumer loans showed no significant increase in the premium spread, so there is little reason for the hypothesis to hold here, and indeed no consistent story emerges from the graphs. And finally, education loans show borrowing probabilities increasing over time across all risk classes, suggesting other exogenous effects are at work in this market.

Several aggregate debt categories are considered: all debt, all debt less mortgages and secured debt. All debt less mortgages is considered in order to ensure that results are not being driven simply by rising real estate prices making home ownership more attractive. All three aggregates bear out the hypothesis. Very high-risk households have a higher probability of holding debt, post-1995. Low-risk borrowers increase debt levels more than high-risk borrowers, and in some cases very high-risk borrowers actually decrease borrowing levels. Finally, consistent with interest rates falling below or rising above reservation rates, low-risk (high-risk) households have a higher (lower) probability of holding debt.

\section{Actual and Predicted Changes Levels and Access to Debt Markets}

That debt levels and the use of debt instruments increased in the 1990s has been the subject of much popular discussion using both data and anecdotal evidence. How much of these changes, pre-1995 to post-1995, can risk-based pricing explain? Answering this question necessitates estimating borrowing levels and use of debt allowing for risk-based pricing but no other changes over this period. Essentially, I need to exclude any economy-wide level effects such as changes in the cost of funds for lenders or general changes in laws and attitudes.

For this analysis, I will need to use default risk quantiles rather than smooth measures of risk. Many households have essentially zero default risk. To estimate the reaction to risk-based pricing for these very low-risk households, I need to represent them by some measure other than zero. Otherwise, any possibly changing coefficient for this risk group, pre- versus post-1995, will be rendered ineffective. The preceding section shows that the borrowing levels of these low-risk 
groups reacted strongly to the increased use of risk-based pricing. Using quantile dummies, I can get different effects before and after 1995 for households with zero default risk. The preceding section's results regarding use of borrowing instruments and debt levels informs the decision for which risk group is restricted to no change in order to identify the model. Robustness checks shows that the choices are quite reasonable.

The following model is estimated for the various types of consumer debt, where $B_{j}$ is the borrowing level for household $j$ :

$$
\begin{aligned}
& \ln \left(\hat{B}_{j}\right)=\gamma^{0}+\gamma^{1} \text { oyears }_{95}+\sum_{i=1}^{4} \gamma^{2} \times(\text { risk class }=\text { iof } 5)+\sum_{i=1}^{4} \gamma_{i}^{3} \text { oyears }_{95} \times(\text { risk class }=\text { iof } 5) \\
& \operatorname{Pr}\left(B_{j}>1\right)=\Phi\left(\begin{array}{l}
\beta^{0}+\beta^{1} \text { years }_{95}+\sum_{i=2}^{10} \beta^{2} \times(\text { risk class }=\text { iof } 10)+ \\
\left.\sum_{i=2}^{10} \beta^{3}{ }_{i} \text { years }_{95} \text { (risk class }=\text { iof } 10\right)+ \text { oborrowing attitudes }
\end{array}\right)
\end{aligned}
$$

For the probit, more risk quantiles are used since some of the most interesting changes for the use of borrowing instruments occur for the very high-risk groups. In fact, the tenth quantile is further divided into four finer divisions of risk. The risk classes for the borrowing levels use conditional bankruptcy risk, and the classes for the probit use unconditional bankruptcy risk.

Figure 3 plots the predicted changes for borrowing levels and use of the debt instrument for first mortgages, automobile loans and all debt for pre-1995 estimation and allowing for riskbased pricing. Probabilities of holding debt are shown as a function of unconditional bankruptcy risk. In contrast, debt levels are shown as a function of conditional bankruptcy risk quantiles. The levels plots are easier to read with simple data points since nearly all the changes take place for households in the first quantile. Since there is nearly zero variation in bankruptcy risk for these households - they are all clustered at zero - smooth plots are difficult to read. $90 \%$ confidence intervals are shown. ${ }^{29}$

${ }^{29}$ These confidence intervals reflect the prediction error in the betas without the additional error associated with the residual. These plots do not represent genuine forecasts of levels and use of debt, only the levels and use predicted by risk-based pricing which is summarized by the coefficients. However, including the error associated with the residual generally makes both sets of confidence intervals so large as to include pre- and post-1995 point estimates. 
Figure 3 also allows us to ask how much in aggregate the model predicts for borrowing levels and use of debt given the changes to loan pricing that occurred in the mid-1990s. These numbers can be compared to the actual changes that took place over this time period. In all, the model predicts anywhere from about $25 \%$ to $75 \%$ of the actual increases in average debt levels. For example, the model predicts that risk-based pricing would have added over $\$ 7,000$ to the average mortgage amount excluding any economy-wide changes. In the data, actual mortgages originated after 1995 versus those originated before 1995 increased about $\$ 30,000$. Similarly for automobile loans, the model predicts an increase of nearly $\$ 1,500$ in the average loan size, whereas actual automobile loans increased over $\$ 2,000$. The average debt burden for households holding debt went up about $\$ 14,000$ over the mid-1990s. The model predicts an increase of nearly $\$ 6,000$.

In contrast, the model over-predicts the increased use of various debt instruments. For first mortgages, there was an actual increase of 3 percentage points of the population holding mortgages from before 1995 to after 1995 in the survey data. The model predicts an increase of nearly 8 percentage points. The percentage of households holding automobiles loans went up only 0.06 point, whereas the model predicts an increase of 0.5 point. The highest risk group had much larger changes. In the data, the percentage holding automobile loans went up 2.6 points, and the model predicts an increase of 3.2 percentage points. For all debt, there was an increase of 2.2 percentage points in the number of families holding any form of debt, and the model predicts an increase of almost 7 points. ${ }^{30}$

\section{Conclusion}

Overall, economists have much less of an understanding of the household's borrowing instruments than saving instruments. Extensive research has been done on how households choose savings portfolios, how returns on those portfolios are determined, and, in turn, what impact the portfolio returns have on the household. In contrast, much less is known about the borrowing portfolio even though roughly $70 \%$ of households hold debt. And, even less is

\footnotetext{
${ }^{30}$ Other changes that were similarly heterogeneous across risk-classes could also account for the models predictions. For example, if attitudes towards risk changed in the same manner that risk-based pricing affected various risk groups - if only the lowest risk groups became exogenously more amenable to high debt levels over the time period - such changes could not be rejected as alternative reasons for the predictions.
} 
understood about the determination of the interest rates on consumer loans, despite their importance in household decision-making.

This paper's goal is to increase our understanding of how consumer loan markets function by examining whether consumer lenders increased their use of risk-based pricing practices in the mid-1990s. In the process, I estimate the extent of default risk's role in interest rate setting by using two sources of risk: the risk of being late on payments and the risk of bankruptcy. Both contribute to the determination of interest rates from 1983 to 1998.

The results indicate that the risk premiums for collateralized loans (first and second mortgages and automobile loans) have risen over time by a significant amount. The case for noncollateralized loans is less clear. The premium for credit card loans more than doubles, but education loan and other consumer loan premiums are statistically unchanged. Finally, the evidence suggests that variations over time in household's level of debt and use of debt instruments are consistent with this change in pricing practices.

Given the effects that risk-based pricing appears to have on debt levels and access to debt, there should be important welfare implications. While very high-risk and low-risk households have benefited from these changes, high-risk households have seen their premiums increase and have changed their borrowing in response. The welfare implications are the subject of future work and are a natural extension of this analysis.

\section{References}

Aaker, David A. and George S. Day (eds.), Consumerism: search for the consumer interest, New York: Free Press, 1971.

Araujo, Aloisio and Mário Páscoa, "Bankruptcy in a Model of Unsecured Claims," Working Paper, 1999.

Ausubel, Lawrence, "The Failure of Competition in the Credit Card Market," American Economic Review, v. 81, n. 1, March, 1991.

Berkowitz, Jeremy and Richard Hynes, "Bankruptcy Exemptions and the Market for Mortgage Loans," Working Paper, 1998.

Bostic, Raphael W., "Trends in Equal Access to Credit Products," in The Impact of Public Policy on Consumer Credit, eds. Thomas Durkin and Michael Staten, Massachusetts: Kluwer Academic Publishers, 2002, pages 171-202. 
Canner, Glenn and Wayne Passmore, "The Community Reinvestment Act and the Profitability of Mortgage-Oriented Banks," Finance and Economics Discussion Series, Federal Reserve Board, Washington, D.C., 1997-7.

Caplovitz, David, The Poor Pay More: Consumer Practices of Low-Income Families, New York: Free Press, 1967.

Chatterjee, Satyajit, Dean Corbae, Makoto Nakajima and José-Víctor Ríos-Rull, “A Quantitative Theory of Unsecured Consumer Credit with Risk of Default," Working Paper, 2002.

Consumer credit and the low income consumer; a study of selected activities by commercial banks, credit unions and retailers to make consumer credit, consumer counseling and consumer education available to low income persons, The Urban Coalition, Maryland: William G. Kaye \& Associates, 1969.

Dahlin, Mike, "Technology Trends Data," www.cs.utexas.edu/users/dahlin/techTrends, 2000.

Deaton, Angus, "The Analysis of Household Surveys," Baltimore, Maryland: Johns Hopkins University Press, World Bank Publication, 1997.

Domowitz, Ian and Robert L. Sartain, "Determinants of the Consumer Bankruptcy Decision," Journal of Finance, v. 45, n. 1, February, 1999, pages 403-420.

Dubey, Pradeep John Geanakoplos and Martin Shubik, "Default and Punishment in General Equilibrium," Cowles Foundation Discussion Paper, 1304RRR, April, 2003.

Duca, John V. and Stuart S. Rosenthal, "Borrowing Constraints, Household Debt, and Racial Discrimination in Loan Markets," Journal of Financial Intermediation, 3, October, 1993, pages $77-103$.

Edelberg, Wendy, "Testing for Racial Discrimination in Consumer Loan Markets," Working Paper, October, 2002.

Fay, Scott, Erik Hurst and Michelle White, "The Bankruptcy Decision," The American Economic Review, v. 92, n. 3, 2002, pages 706-718.

Freeman and Hamilton, “A Dream Deferred or Realized,” AEA Proceedings, v. 92, n. 2, 2002.

Geanakoplos, John, "Liquidity, Default and Crashes: Endogenous Contracts in General Equilibrium," Cowles Foundation Discussion Paper, 1316RR, June, 2002.

Gropp, Reint, John K. Scholz and Michelle J. White, "Personal Bankruptcy and Credit Supply and Demand," Quarterly Journal of Economics; 448(1), 1997, pages 217-252.

Gross, David and Nicholas Souleles, "Do Liquidity Constraints and Interest Rates Matter for Consumer Behavior? Evidence from Credit Card Data," National Bureau of Economic Research, Working Paper 8314, 2001.

Gross, David and Nicholas Souleles, "Explaining the Increase in Bankruptcy and Delinquency: Stigma versus Risk-Composition," Working Paper, 1999.

Han, Song, "Credit Risk, Discrimination, and Regulation in Credit Markets," University of Chicago Dissertation, Chicago, Illinois, 1998. 
Hester, Donald, "An Empirical Examination of a Commercial Bank Loan Offer Function," in Studies of Portfolio Behavior, eds. Donald Hester and James Tobin, New York: John Wiley and Sons, 1967, pages 118-170.

Jappelli, Tullio, "Who is Credit Constrained in the U.S. Economy?" Quarterly Journal of Economics; 105(1), February 1990, pages 219-234.

Jappelli, Tullio, Jorn-Steffen Pischke and Nicholas Souleles, "Testing for Liquidity Constraints in Euler Equations with Complementary Data Sources," Review of Economics and Statistics; 1998, pages 251-262.

Johnson, Kathleen, "Consumer Loan Securitization," in The Impact of Public Policy on Consumer Credit, eds. Thomas Durkin and Michael Staten, Massachusetts: Kluwer Academic Publishers, 2002, pages 287-306.

Johnson, R.W., "Legal, Social and Economic Issues in Implementing Scoring in the United States," in Credit scoring and credit control: based on the proceedings of a conference on credit scoring and credit control, organized by the Institute of Mathematics and Its Applications and held at the University of Edinburgh in August 1989, eds. J.N. Crook, D.B. Edelman and L. C. Thomas, New York: Oxford University Press, 1992.

Kennickell, Arthur B., Starr-McCluer, Martha, and Brian J. Surette, "Recent Changes in U.S. Family Finances: Results from the 1998 Survey of Consumer Finances," Federal Reserve Bulletin; 86(1), January 2000, pages 1-29.

Manning, Robert D., Credit Card Nation, New York: Basic Books, 2000.

McCorkell, Peter L., "The Impact of Credit Scoring and Automated Underwriting on Credit Availability," in The Impact of Public Policy on Consumer Credit, eds. Thomas Durkin and Michael Staten, Massachusetts: Kluwer Academic Publishers, 2002, pages 209-219.

Murphy, Kevin and Robert Topel, "Estimation and Inference in Two-Step Econometric Models," Journal of Business and Economic Statistics, v.3, n.4, October, 1985, pages 88-97.

Runkle, David, "Liquidity Constraints and the Permanent-Income Hypothesis: Evidence from Panel Data," Journal of Monetary Economics; 27(1), February 1991, pages 73-98.

Sullivan, Teresa A., Elizabeth Warren, and Jay L. Westbrook, As We Forgive Our Debtors: Bankruptcy and Consumer Credit in America, New York: Oxford University Press, 1989.

Sullivan, Teresa A., Elizabeth Warren, and Jay L. Westbrook, The Fragile Middle Class: Americans in Debt, Connecticut: Yale University Press, 2000.

Winton, E. Williams, Games Creditors Play: Collecting from Overextended Consumers, North Carolina: Carolina Academic Press, 1998.

Yezer, Anthony, "Discussion of Trends in Equal Access to Credit Products," in The Impact of Public Policy on Consumer Credit, eds. Thomas Durkin and Michael Staten, Massachusetts: Kluwer Academic Publishers, 2002, pages 203-205.

Zeldes, Stephen, "Consumption and Liquidity Constraints: An Empirical Investigation," Journal of Political Economy; 97(2), April 1989, pages 305-46. 


\section{Tables}

Table 1. Interest Rate Data for loans originated in 1998

\begin{tabular}{l|lll}
\hline & Mean & $\begin{array}{l}\text { Standard } \\
\text { Interest Rate }\end{array}$ & $\begin{array}{l}\text { Observations across } \\
\text { all origination years }\end{array}$ \\
\hline$I^{\text {st }}$ Mortgage Rate & $7.75 \%$ & 1.53 & 8,143 \\
$2^{\text {nd }}$ Mortgage Rate & 10.57 & 2.63 & 805 \\
Auto Loan Rate & 9.92 & 4.53 & 5,209 \\
Credit Card Rate & 14.45 & 5.01 & 4,007 \\
Other Consumer Loan Rate & 13.28 & 6.69 & 2,744 \\
Education Loan Rate & 8.35 & 1.96 & 997 \\
\hline
\end{tabular}

Table 2. Attitudinal variables vs. debt

\begin{tabular}{l|l|l|l|l|l|l|l|}
\hline & $\begin{array}{l}1^{\text {st }} \\
\text { Mortgage } \\
38 \% * *\end{array}$ & $\begin{array}{l}2^{\text {nd }} \\
\text { Mortgage } \\
4 \%\end{array}$ & $\begin{array}{l}\text { Auto } \\
\text { Loan } \\
30 \%\end{array}$ & $\begin{array}{l}\text { Other } \\
\text { Consumer } \\
22 \%\end{array}$ & $\begin{array}{l}\text { Credit } \\
\text { Card } \\
39 \%\end{array}$ & $\begin{array}{l}\text { Education } \\
\text { Loan } \\
4 \%\end{array}$ & $\begin{array}{l}\text { Any } \\
\text { debt } \\
72 \%\end{array}$ \\
\hline $\begin{array}{l}\text { Borrowing } \text { is } \\
\text { generally good }- \\
40 \% *\end{array}$ & $38 \%$ & $4 \%$ & $34 \%$ & $23 \%$ & $30 \%$ & $3 \%$ & $77 \%$ \\
\hline $\begin{array}{l}\text { Borrowing is } \\
\text { generally okay }-31 \%\end{array}$ & 39 & 5 & 29 & 18 & 29 & 4 & 73 \\
\hline $\begin{array}{l}\text { Borrowing } \text { is ok } \\
\text { for...vacation }-14 \%\end{array}$ & 39 & 5 & 33 & 25 & 37 & 5 & 81 \\
\hline$\ldots$ cut in income - \\
$45 \%$
\end{tabular}

Frequencies reported are the percentage of all the households who responded "yes" for the attitudinal variables that also hold the relevant form of debt. * these are the percentages of those responding "yes" in the total population ** percentage of households holding each kind of debt. 
Table 3. Declaration of Bankruptcy, Conditional Probability

\begin{tabular}{|c|c|c|c|c|}
\hline & Coefficient & $\begin{array}{l}\text { Robust } \\
\text { Standard Error }\end{array}$ & $p$-value & $\partial($ probability $) / \partial x$ \\
\hline $1989 *$ & 0.319 & 0.174 & 0.067 & 0.0051 \\
\hline 1994* & 0.470 & 0.156 & 0.003 & 0.0068 \\
\hline Age & 0.011 & 0.020 & 0.588 & $1.38 \mathrm{E}-04$ \\
\hline Age squared & $-2.49 \mathrm{E}-04$ & $2.27 \mathrm{E}-04$ & 0.272 & $-3.25 \mathrm{E}-06$ \\
\hline No checking account* & 0.305 & 0.091 & 0.001 & 0.0052 \\
\hline Ln(Income) & 0.056 & 0.032 & 0.080 & 0.0007 \\
\hline Self employed* & 0.287 & 0.126 & 0.022 & 0.0051 \\
\hline Home Ownership* & 0.302 & 0.176 & 0.087 & 0.0035 \\
\hline Home Ownership x 1989* & -0.210 & 0.218 & 0.335 & -0.0023 \\
\hline Home Ownership x 1994* & -0.405 & 0.199 & 0.041 & -0.0045 \\
\hline NC Debt/Income $>2 *$ & 0.328 & 0.261 & 0.209 & 0.0066 \\
\hline Positive Net worth & $-3.35 \mathrm{E}-06$ & $1.07 \mathrm{E}-06$ & 0.002 & $-4.37 \mathrm{E}-08$ \\
\hline Non-collateralized Debt & $1.70 \mathrm{E}-06$ & $8.98 \mathrm{E}-07$ & 0.058 & $2.22 \mathrm{E}-08$ \\
\hline Unemployed $^{*}$ & -0.309 & 0.230 & 0.180 & -0.0028 \\
\hline Black* $^{*}$ & -0.110 & 0.091 & 0.227 & -0.0013 \\
\hline Education Class & -0.105 & 0.041 & 0.011 & -0.0014 \\
\hline Single Parent* & 0.165 & 0.101 & 0.103 & 0.0026 \\
\hline Constant & -2.892 & 0.516 & 0.000 & \\
\hline
\end{tabular}

$* \mathrm{~d}($ probability)/dx is for discrete change of dummy variable from 0 to 1 
Table 4. Declaration of Bankruptcy, Unconditional Probability

\begin{tabular}{|c|c|c|c|c|}
\hline & Coefficient & $\begin{array}{l}\text { Robust } \\
\text { Standard Error }\end{array}$ & $p$-value & $\partial($ probability $) / \partial x$ \\
\hline $1989^{*}$ & 0.328 & 0.110 & 0.003 & 0.0037 \\
\hline 1994* & 0.368 & 0.095 & 0.000 & 0.0034 \\
\hline Age & 0.017 & 0.015 & 0.253 & $1.49 \mathrm{E}-04$ \\
\hline Age squared & $-3.06 \mathrm{E}-04$ & 1.69E-04 & 0.071 & $-2.68 \mathrm{E}-06$ \\
\hline No checking account* & 0.252 & 0.083 & 0.002 & 0.0026 \\
\hline Ln(Income) & 0.082 & 0.033 & 0.015 & 0.0007 \\
\hline Self employed* & 0.228 & 0.110 & 0.038 & 0.0026 \\
\hline Assets* $^{*}$ & $-8.02 \mathrm{E}-07$ & $4.38 \mathrm{E}-07$ & 0.067 & $-7.01 \mathrm{E}-09$ \\
\hline Assets $x 1989^{*}$ & $-9.60 \mathrm{E}-07$ & 8.03E-07 & 0.232 & $-8.39 \mathrm{E}-09$ \\
\hline Assets x 1994* & $-1.74 \mathrm{E}-06$ & $7.36 \mathrm{E}-07$ & 0.018 & $-1.52 \mathrm{E}-08$ \\
\hline Unemployed* & -0.307 & 0.174 & 0.077 & -0.0019 \\
\hline Black* & -0.158 & 0.080 & 0.048 & -0.0013 \\
\hline Education Class & -0.018 & 0.038 & 0.633 & -0.0002 \\
\hline Single Parent* & 0.079 & 0.086 & 0.359 & 0.0007 \\
\hline Constant & -3.461 & 0.449 & 0.000 & \\
\hline
\end{tabular}

* $\mathrm{d}($ probability $) / \mathrm{dx}$ is for discrete change of dummy variable from 0 to 1

Table 5. Predicted bankruptcy rates (in fractions) within two years of survey date

\begin{tabular}{|l|l|l|l|l|}
\multicolumn{1}{c}{} & \multicolumn{2}{c}{ Conditional Estimates } & \multicolumn{2}{l|}{ Unconditional Estimates } \\
\cline { 2 - 5 } \multicolumn{1}{c|}{} & PSID & $S C F$ & $P S I D$ & $S C F$ \\
\hline Percentiles: $1 \%$ & 0.0000 & 0.0000 & 0.0000 & 0.0000 \\
\hline $10 \%$ & 0.0002 & 0.0001 & 0.0001 & 0.0001 \\
\hline $25 \%$ & 0.0019 & 0.0012 & 0.0021 & 0.0013 \\
\hline $50 \%$ & 0.0067 & 0.0058 & 0.0061 & 0.0049 \\
\hline $75 \%$ & 0.0143 & 0.0134 & 0.0117 & 0.0113 \\
\hline $90 \%$ & 0.0216 & 0.0228 & 0.0179 & 0.0174 \\
\hline $99 \%$ & 0.0514 & 0.0531 & 0.0340 & 0.0330 \\
\hline Range & $0.00-0.24$ & $0.00-0.86$ & $0.00-0.059$ & $0.00-0.99$ \\
\hline Mean & 0.0099 & 0.0091 & 0.0080 & 0.0073 \\
\hline Standard Deviation & 0.0116 & 0.0145 & 0.0077 & 0.0077 \\
\hline
\end{tabular}


Table 6. Characteristics by Conditional Bankruptcy Probability Quantiles

\begin{tabular}{|c|c|c|c|c|c|c|}
\hline & $\begin{array}{l}1^{\text {st }} \\
\text { Quantile }\end{array}$ & $\begin{array}{l}2^{\text {nd }} \\
\text { Quantile }\end{array}$ & $3^{\text {rd }}$ Quantile & $4^{\text {th }}$ Quantile & $\begin{array}{l}5^{\text {th }} \\
\text { Quantile }\end{array}$ & $\begin{array}{l}\text { Overall } \\
\text { Average }\end{array}$ \\
\hline Bankruptcy Probability & $0.0 \%$ & $0.2 \%$ & $0.6 \%$ & $1.2 \%$ & $2.8 \%$ & $0.9 \%$ \\
\hline Age & 55.48 & 51.18 & 43.72 & 37.84 & 33.54 & 44.35 \\
\hline No Checking Account* & 0.028 & 0.026 & 0.067 & 0.110 & 0.387 & 0.124 \\
\hline Income & $\$ 106,000$ & $\$ 48,800$ & $\$ 42,750$ & $\$ 37,620$ & $\$ 27,680$ & $\$ 52,580$ \\
\hline Self Employed* & 0.217 & 0.099 & 0.069 & 0.080 & 0.135 & 0.120 \\
\hline Home Ownership* & 0.919 & 0.840 & 0.751 & 0.607 & 0.346 & 0.693 \\
\hline $\begin{array}{l}\text { Non-collateralized } \\
\text { Debt/Income }>0.2^{*}\end{array}$ & 0.039 & 0.006 & 0.005 & 0.003 & 0.044 & 0.019 \\
\hline Net Worth & $\$ 885,700$ & $\$ 141,000$ & $\$ 70,980$ & $\$ 34,100$ & $\$ 10,930$ & $\$ 228,600$ \\
\hline Non-collateralized Debt & 4,976 & 3,139 & 3,310 & 4,297 & 6,661 & 4,477 \\
\hline Unemployed* & 0.068 & 0.091 & 0.073 & 0.047 & 0.056 & 0.067 \\
\hline Black* & 0.063 & 0.115 & 0.128 & 0.134 & 0.141 & 0.116 \\
\hline Years of Education & 14.41 & 13.38 & 13.13 & 13.00 & 11.83 & 13.15 \\
\hline Single Parent* & 0.047 & 0.054 & 0.085 & 0.119 & 0.243 & 0.109 \\
\hline
\end{tabular}

$*$ Number reported is proportion of population. 
Table 7. Late Payment Indicator

\begin{tabular}{|c|c|c|c|}
\hline & Coefficient & $\begin{array}{l}\text { Robust Standard } \\
\text { Error }\end{array}$ & $p$-value \\
\hline 1989 & 0.724 & 0.407 & 0.08 \\
\hline 1992 & -0.077 & 0.173 & 0.66 \\
\hline 1995 & -0.399 & 0.135 & 0.00 \\
\hline 1998 & -0.106 & 0.142 & 0.46 \\
\hline Age & 0.026 & 0.009 & 0.00 \\
\hline Age squared & $-4.47 \mathrm{E}-04$ & $9.81 \mathrm{E}-05$ & 0.00 \\
\hline No checking account & 0.346 & 0.058 & 0.00 \\
\hline Ln(Income) & 0.014 & 0.007 & 0.03 \\
\hline$\ldots \times 1989$ & -0.121 & 0.039 & 0.00 \\
\hline ...x 1992 & -0.038 & 0.015 & 0.01 \\
\hline ...x 1995 & 0.006 & 0.011 & 0.58 \\
\hline$\ldots \times 1998$ & -0.025 & 0.012 & 0.04 \\
\hline Self employed & -0.032 & 0.094 & 0.73 \\
\hline$\ldots \times 1989$ & 0.198 & 0.161 & 0.22 \\
\hline ...x 1992 & 0.285 & 0.145 & 0.05 \\
\hline ...x 1995 & 0.047 & 0.153 & 0.76 \\
\hline$\ldots \times 1998$ & 0.247 & 0.153 & 0.11 \\
\hline Home Ownership & -0.097 & 0.072 & 0.18 \\
\hline$\ldots \times 1989$ & -0.188 & 0.123 & 0.12 \\
\hline ...x 1992 & -0.229 & 0.112 & 0.04 \\
\hline ...x 1995 & -0.206 & 0.107 & 0.05 \\
\hline$\ldots \times 1998$ & -0.059 & 0.113 & 0.60 \\
\hline NC Debt/Income $>2.5$ & 0.370 & 0.123 & 0.00 \\
\hline Positive Net worth & $-7.00 \mathrm{E}-08$ & 4.66E-08 & 0.13 \\
\hline$\ldots \times 1989$ & $6.18 \mathrm{E}-08$ & $4.75 \mathrm{E}-08$ & 0.19 \\
\hline$\ldots \times 1992$ & 7.41E-09 & 5.65E- 08 & 0.90 \\
\hline$\ldots \times 1995$ & $-6.05 \mathrm{E}-08$ & $9.11 \mathrm{E}-08$ & 0.51 \\
\hline$\ldots \times 1998$ & $-5.85 \mathrm{E}-07$ & $2.55 \mathrm{E}-07$ & 0.02 \\
\hline Non-collateralized Debt & $1.40 \mathrm{E}-07$ & $1.10 \mathrm{E}-07$ & 0.20 \\
\hline Unemployed & 0.188 & 0.102 & 0.07 \\
\hline$\ldots \times 1989$ & 0.238 & 0.192 & 0.22 \\
\hline$\ldots \times 1992$ & -0.533 & 0.216 & 0.01 \\
\hline$\ldots \times 1995$ & -0.271 & 0.208 & 0.19 \\
\hline$\ldots \times 1998$ & 0.040 & 0.188 & 0.83 \\
\hline Black & 0.484 & 0.086 & 0.00 \\
\hline ...x 1989 & -0.107 & 0.153 & 0.49 \\
\hline ...x 1992 & -0.259 & 0.155 & 0.10 \\
\hline$\ldots \times 1995$ & -0.247 & 0.145 & 0.09 \\
\hline$\ldots \times 1998$ & -0.183 & 0.136 & 0.18 \\
\hline Education Class & -0.091 & 0.016 & 0.00 \\
\hline Single Parent & 0.122 & 0.053 & 0.02 \\
\hline Constant & -1.234 & 0.203 & 0.00 \\
\hline
\end{tabular}




\section{Table 7, continued}

Selection Equation

\begin{tabular}{|l|l|l|l|}
\hline \multicolumn{1}{l|}{} & Coefficient & $\begin{array}{l}\text { Robust Standard } \\
\text { Error }\end{array}$ & -value \\
\hline 1989 & 0.098 & 0.036 & 0.01 \\
\hline 1992 & 0.083 & 0.034 & 0.02 \\
\hline 1998 & 0.060 & 0.033 & 0.07 \\
\hline Age & 0.067 & 0.033 & 0.04 \\
\hline Age squared & 0.041 & 0.004 & 0.00 \\
\hline No checking account & $-7.24 \mathrm{E}-04$ & $4.17 \mathrm{E}-05$ & 0.00 \\
\hline Ln(Income) & -0.478 & 0.036 & 0.00 \\
\hline Self employed & 0.004 & 0.003 & 0.16 \\
\hline Home Ownership & -0.054 & 0.028 & 0.06 \\
\hline Positive Net worth & 0.629 & 0.028 & 0.00 \\
\hline Unemployed & $-2.26 \mathrm{E}-09$ & $6.34 \mathrm{E}-10$ & 0.00 \\
\hline Black & -0.335 & 0.042 & 0.00 \\
\hline Education Class & 0.136 & 0.040 & 0.00 \\
\hline Single Parent & 0.036 & 0.009 & 0.00 \\
\hline borrowing is good & 0.068 & 0.040 & 0.09 \\
\hline borrowing is okay & 0.228 & 0.028 & 0.00 \\
\hline $\begin{array}{l}\text { Borrowing is okay... } \\
\text { for vacation }\end{array}$ & 0.115 & 0.027 & 0.00 \\
\hline for a cut in income & 0.147 & 0.035 & 0.00 \\
\hline for furs and jewelry & -0.035 & 0.023 & 0.13 \\
\hline for a car & 0.028 & 0.050 & 0.57 \\
\hline for education & 0.390 & 0.028 & 0.00 \\
\hline Constant & -0.027 & 0.030 & 0.37 \\
\hline
\end{tabular}

Table 8. Predicted Probability of Late Payments (in fractions)

\begin{tabular}{|l|l|}
\cline { 2 - 2 } \multicolumn{1}{c|}{} & SCF \\
\hline Percentiles: $1 \%$ & 0.001 \\
\hline $10 \%$ & 0.010 \\
\hline $25 \%$ & 0.026 \\
\hline $50 \%$ & 0.056 \\
\hline $75 \%$ & 0.118 \\
\hline $90 \%$ & 0.207 \\
\hline $99 \%$ & 0.479 \\
\hline Range & $0.000-0.99$ \\
\hline Mean & 0.089 \\
\hline Standard Deviation & 0.098 \\
\hline
\end{tabular}


Table 9. Interest Rates Moments by Origination Year and Risk Classes over Time

\begin{tabular}{|l|l|l|l|l|l|l|}
\hline & $\begin{array}{l}1989 \text { High- } \\
\text { risk vs. Low- } \\
\text { risk Spread }\end{array}$ & $\begin{array}{l}\text { 1995 High- } \\
\text { risk vs. Low- } \\
\text { risk Spread }\end{array}$ & $\begin{array}{l}1998 \text { High- } \\
\text { riskvs. Low- } \\
\text { risk Spread }\end{array}$ & $\begin{array}{l}1989 \\
\text { standard } \\
\text { deviation }\end{array}$ & $\begin{array}{l}1995 \\
\text { standard } \\
\text { deviation }\end{array}$ & $\begin{array}{l}1998 \\
\text { standard } \\
\text { deviation }\end{array}$ \\
\hline$I^{\text {st }}$ Mortgage Rate $^{*}$ & 0.53 & 0.59 & 0.69 & 1.16 & 1.26 & $1.49^{\dagger \dagger}$ \\
\hline $2^{\text {nd }}$ Mortgage & 2.65 & 1.75 & 2.84 & 2.21 & $2.82^{\dagger \dagger}$ & 2.63 \\
\hline Auto Loan & 1.40 & $2.42^{\dagger \dagger}$ & $3.94^{\dagger \dagger}$ & 3.58 & $4.05^{\dagger \dagger}$ & $4.53^{\dagger \dagger}$ \\
\hline Credit Card & -0.99 & $1.05^{\dagger \dagger}$ & 1.22 & 4.18 & $4.43^{\dagger \dagger}$ & $5.01^{\dagger \dagger}$ \\
\hline Other Consumer Loan & 0.08 & $3.03^{\dagger \dagger}$ & 4.06 & 4.47 & $6.07^{\dagger \dagger}$ & 6.69 \\
\hline Education Loan & -0.02 & 1.30 & 0.26 & 3.37 & $4.05^{\dagger \dagger}$ & 1.96 \\
\hline
\end{tabular}

* To reduce raw variance in mortgage rates simply due to mortgage terms, only 30 year fixed rate mortgages are considered here.

** As credit card rates are not available for 1989, 1983 is used where the table indicates 1989.

${ }^{\dagger}$ In order to have a reasonable number of observations, 1998 spreads are taken from years 1998 and 1997,1995 spreads represent years 1995 and 1996, and 1989 spreads are computed for 1988 and 1987 (except for credit card rates which are computed for single years).

${ }^{\dagger}$ Difference between current and preceding year's number is significant with p-value $<0.1$.

Note that standard deviations of 30-year fixed Treasury bond rates were 0.50, 0.57 and 0.36 in 1989, 1995 and 1998 , respectively.

Table 10. Default Risk Premium Spreads

\begin{tabular}{l|ll}
\hline & Pre-1995 Risk & Post-1995 Risk \\
& Premium Spread & Premium Spread \\
\hline $1^{\text {st }}$ Mortgage Rate* & 0.50 & 0.98 \\
$2^{\text {nd }}$ Mortgage Rate* & 0.98 & 3.97 \\
Auto Loan Rate* & 1.08 & 1.94 \\
General Consumer Loan Rate & 1.19 & 1.08 \\
Credit Card Rate* & $-0.53^{* *}$ & 1.30 \\
Education Loan Rate & $0.03^{* *}$ & $0.41^{* *}$ \\
\hline
\end{tabular}

* Difference is significant at a 95\% confidence level. ** Spread is insignificantly different from zero. 
Table 11. Default Risk Premium Spreads from Alternative Models

\begin{tabular}{|c|c|c|c|c|c|}
\hline & $\begin{array}{l}\text { Base } \\
\text { Model }\end{array}$ & $\begin{array}{l}\text { Late Payments } \\
\text { replaces p(late } \\
\text { payments) }\end{array}$ & $\begin{array}{l}I_{96} \\
\text { replaces } \\
I_{95}\end{array}$ & $\begin{array}{l}\text { No } \\
\text { P(bankruptcy) }\end{array}$ & $\begin{array}{l}\text { No P(late } \\
\text { payments) }\end{array}$ \\
\hline \multicolumn{6}{|l|}{ Pre-1995 } \\
\hline$I^{\text {st }}$ Mortgage Rate & 0.50 & 0.23 & 0.51 & 0.45 & 0.17 \\
\hline $2^{\text {nd }}$ Mortgage Rate & 0.98 & 0.61 & 1.02 & 0.78 & $0.52^{*}$ \\
\hline Auto Loan Rate & 1.08 & 0.99 & 1.19 & 0.63 & 0.99 \\
\hline General Consumer Loan Rate & 1.19 & 0.35 & 1.18 & 1.23 & $0.16^{*}$ \\
\hline Credit Card Rate & $-0.53^{*}$ & -1.02 & 0.58 & $-0.30^{*}$ & -1.11 \\
\hline Education Loan Rate & $0.03^{*}$ & $0.01^{*}$ & $0.02^{*}$ & $0.11^{*}$ & $-0.02^{*}$ \\
\hline \multicolumn{6}{|l|}{ Post-1995 } \\
\hline $1^{\text {st }}$ Mortgage Rate & 0.98 & 0.97 & 1.00 & 0.66 & 0.90 \\
\hline $2^{\text {nd }}$ Mortgage Rate & 3.97 & 3.90 & 4.16 & 3.04 & 3.88 \\
\hline Auto Loan Rate & 1.94 & $0.99^{\mathrm{d}}$ & 2.12 & 1.90 & $0.77^{* d}$ \\
\hline General Consumer Loan Rate & $1.08^{\mathrm{d}}$ & $0.05^{* d}$ & $1.23^{\mathrm{d}}$ & $1.15^{\mathrm{d}}$ & $-0.01^{* d}$ \\
\hline Credit Card Rate & 1.30 & 0.80 & 1.31 & 1.20 & 0.58 \\
\hline Education Loan Rate & $0.41^{* d}$ & $0.66^{* d}$ & $0.56^{* d}$ & 0.69 & $0.54^{* d}$ \\
\hline
\end{tabular}

All spreads and differences in spreads are statistically significant unless otherwise noted.

*Spread is insignificant.

${ }^{\mathrm{d}}$ Difference in spreads is insignificant. 
Table 12. Coefficients from Base Model and Alternative Models

\begin{tabular}{|c|c|c|c|c|c|}
\hline & $\begin{array}{l}\text { Base } \\
\text { Model }\end{array}$ & $\begin{array}{l}\text { Late Payments } \\
\text { replaces } P \text { (Late } \\
\text { Payments) }\end{array}$ & $\begin{array}{l}I_{96} \text { replaces } \\
I_{95}\end{array}$ & $\begin{array}{l}\text { No } \\
\text { P(bankruptcy) }\end{array}$ & $\begin{array}{l}\text { No P(Late } \\
\text { Payments) }\end{array}$ \\
\hline \multicolumn{6}{|c|}{$1^{\text {st }}$ mortgage rate coefficients } \\
\hline Loan amount & $-1.04 \mathrm{e}-7$ & $-1.50 \mathrm{e}-7^{*}$ & $-1.11 \mathrm{e}-7$ & $-1.04 \mathrm{e}-7$ & $-1.51 \mathrm{e}-7 *$ \\
\hline Equity in home & $-8.34 \mathrm{e}-8 *$ & $-1.33 e-7 *$ & $-8.36 \mathrm{e}-8^{*}$ & $-8.48 \mathrm{e}-8^{*}$ & $-1.46 \mathrm{e}-7^{*}$ \\
\hline P(bankruptcy) & 2.46 & $5.34 *$ & 2.68 & & $6.14 *$ \\
\hline P(Late Payments) & $4.34 *$ & $0.61 *$ & $4.38^{*}$ & $4.47 *$ & \\
\hline$P\left(\right.$ bankruptcy) $* I_{95}$ & $21.79 *$ & $26.49 *$ & $23.84^{*}$ & & $26.55^{*}$ \\
\hline P(Late Payments $) * I_{95}$ & -1.28 & 0.06 & -1.74 & 2.17 & \\
\hline Constant & $16.77 *$ & $8.82 *$ & $16.75^{*}$ & $16.73 *$ & $8.82 *$ \\
\hline \multicolumn{6}{|c|}{$2^{\text {nd }}$ mortgage rate coefficients } \\
\hline Loan amount & $-2.19 \mathrm{e}-6^{*}$ & $-2.23 e-6^{*}$ & $-2.21 e-6^{*}$ & $-2.19 \mathrm{e}-6^{*}$ & $-2.32 \mathrm{e}-6^{*}$ \\
\hline Equity in home & $6.47 \mathrm{e}-9$ & $-7.20 \mathrm{e}-8$ & $1.20 \mathrm{e}-8$ & $-1.61 \mathrm{e}-8$ & $-1.62 \mathrm{e}-7$ \\
\hline P(bankruptcy) & 8.66 & 15.66 & 9.59 & & 18.67 \\
\hline P(Late Payments) & $7.41 *$ & $1.28 *$ & $7.51 *$ & $7.81 *$ & \\
\hline P(bankruptcy) $* I_{95}$ & $100.22 *$ & $116.64 *$ & $112.48 *$ & & $121.52 *$ \\
\hline$P($ Late Payments $) * I_{95}$ & 2.23 & 0.42 & 0.39 & $22.58 *$ & \\
\hline Constant & $19.11^{*}$ & $10.53 *$ & $19.15^{*}$ & $18.99 *$ & $21.14 *$ \\
\hline \multicolumn{6}{|c|}{ Automobile rate coefficients } \\
\hline Loan amount & $-1.3 e-5^{*}$ & $-1.91 \mathrm{e}-5^{*}$ & $-1.33 e-5 *$ & $-1.42 \mathrm{e}-5^{*}$ & $-2.02 \mathrm{e}-5 *$ \\
\hline Equity in auto & $2.48 \mathrm{e}-7$ & $2.56 \mathrm{e}-7$ & $2.92 \mathrm{e}-7$ & $2.97 \mathrm{e}-7$ & $2.54 \mathrm{e}-7$ \\
\hline P(bankruptcy) & $22.20 *$ & $34.64 *$ & $25.86^{*}$ & & $35.90 *$ \\
\hline P(Late Payments) & $4.65 *$ & 0.25 & $4.75 *$ & $6.32 *$ & \\
\hline P(bankruptcy) $* I_{95}$ & -19.36 & -9.23 & $-26.42 *$ & & -8.20 \\
\hline$P($ Late Payments $) * I_{95}$ & $13.99 *$ & $1.81^{*}$ & $16.61 *$ & $12.70 *$ & \\
\hline Constant & $16.72 *$ & $17.74 *$ & $16.70^{*}$ & $16.48 *$ & $17.74 *$ \\
\hline \multicolumn{6}{|c|}{ General Consumer Loan coefficients } \\
\hline Loan amount & $-1.33 \mathrm{e}-7$ & $-1.05 \mathrm{e}-7$ & $-1.34 \mathrm{e}-7$ & $-1.28 \mathrm{e}-7$ & $-9.89 e-8$ \\
\hline Loan Balance & $-5.88 \mathrm{e}-7 *$ & $-7.23 e-7 *$ & $-5.81 e-7 *$ & $-6.22 \mathrm{e}-7^{*}$ & $-7.72 \mathrm{e}-7 *$ \\
\hline P(bankruptcy) & -1.78 & 3.49 & -1.93 & & 5.95 \\
\hline P(Late Payments) & $12.45 *$ & $1.81 *$ & $12.37^{*}$ & $12.38 *$ & \\
\hline$P($ bankruptcy $) * I_{95}$ & -6.85 & -3.41 & $-7.52 *$ & & -6.45 \\
\hline$P($ Late Payments $) * I_{95}$ & 0.75 & -1.44 & 2.52 & -0.86 & \\
\hline Constant & $11.08^{*}$ & $14.48^{*}$ & $11.07^{*}$ & $11.03 *$ & $15.21 *$ \\
\hline \multicolumn{6}{|c|}{ Credit card loan coefficients } \\
\hline Loan Balance & $2.10 \mathrm{e}-5^{*}$ & $1.70 \mathrm{e}-5^{*}$ & $1.99 \mathrm{e}-5^{*}$ & $2.19 \mathrm{e}-5^{*}$ & $1.80 \mathrm{e}-5^{*}$ \\
\hline P(bankruptcy) & -9.23 & $-37.09 *$ & $31.02 *$ & & $-40.44 *$ \\
\hline P(Late Payments) & -2.74 & -0.16 & -2.80 & -3.05 & \\
\hline$P($ bankruptcy $) * I_{95}$ & 19.51 & $56.27^{*}$ & $-23.04 *$ & & $61.52 *$ \\
\hline$P($ Late Payments $) * I_{95}$ & $12.90 *$ & $2.03 *$ & $13.68 *$ & $15.04 *$ & \\
\hline Constant & $13.20^{*}$ & $13.98 *$ & $13.31^{*}$ & $13.17^{*}$ & $14.12 *$ \\
\hline \multicolumn{6}{|c|}{ Education loan coefficients } \\
\hline Loan amount & $1.58 \mathrm{e}-5 *$ & $1.59 \mathrm{e}-5^{*}$ & $1.54 \mathrm{e}-5^{*}$ & $1.48 \mathrm{e}-5 *$ & $1.37 \mathrm{e}-5 *$ \\
\hline P(bankruptcy) & -6.67 & -11.76 & -6.70 & & -0.86 \\
\hline P(Late Payments) & 2.11 & 3.39 & 2.10 & 1.13 & \\
\hline P(bankruptcy) $* I_{95}$ & -15.20 & 17.33 & -9.99 & & 20.56 \\
\hline$P($ Late Payments $) * I_{95}$ & $8.03 *$ & 1.27 & 8.15 & $5.80 *$ & \\
\hline Constant & $17.19 *$ & $17.19 *$ & $17.23 *$ & $17.05^{*}$ & $17.20^{*}$ \\
\hline
\end{tabular}

The origination year dummies are suppressed for readability. ${ }^{*}$ Coefficients with p-values $<0.1$. 
Appendix A. Figures

Figure 1. Predicted Interest Rates plotted against Conditional Bankruptcy Risk
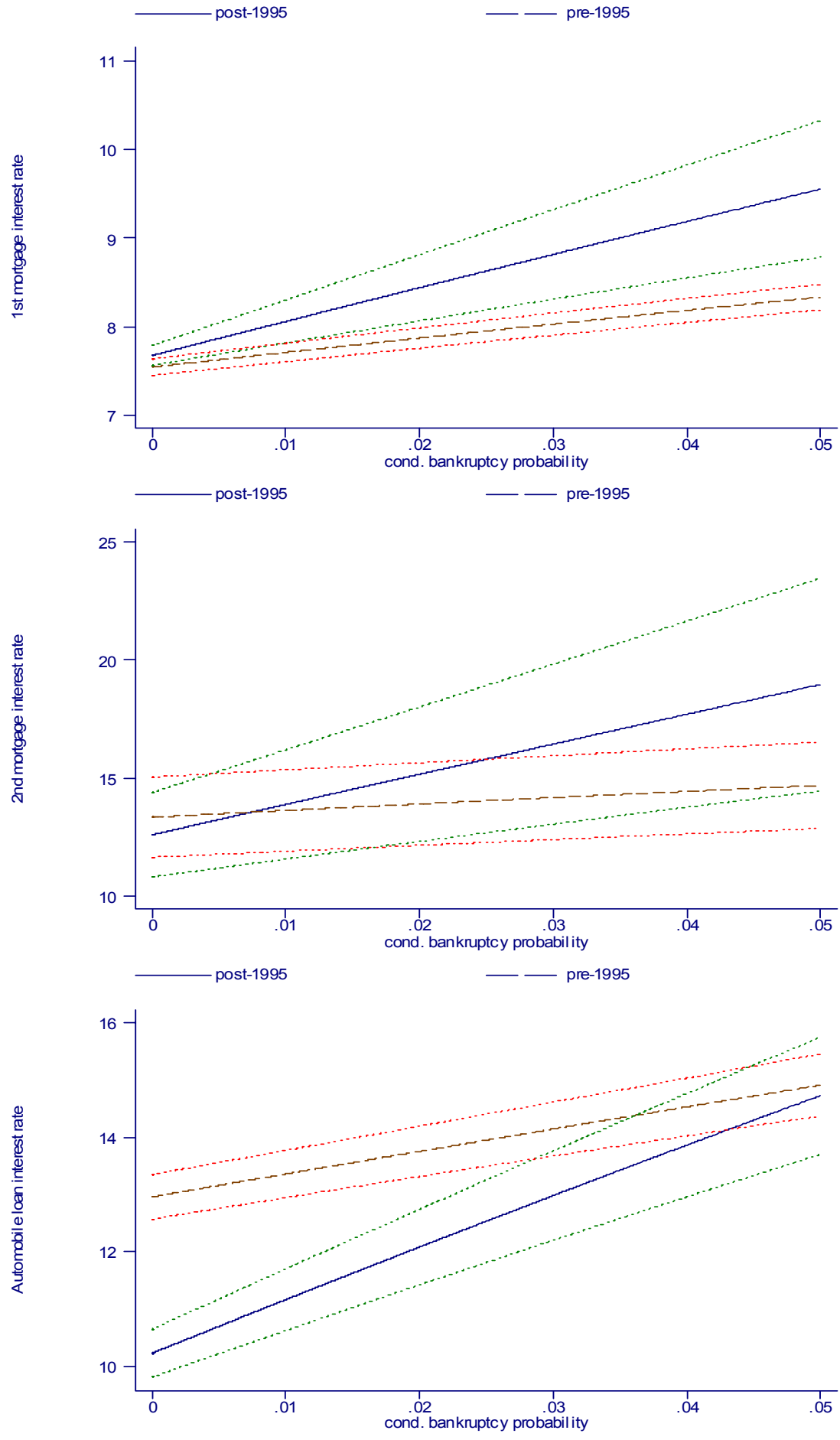
Figure 1, continued
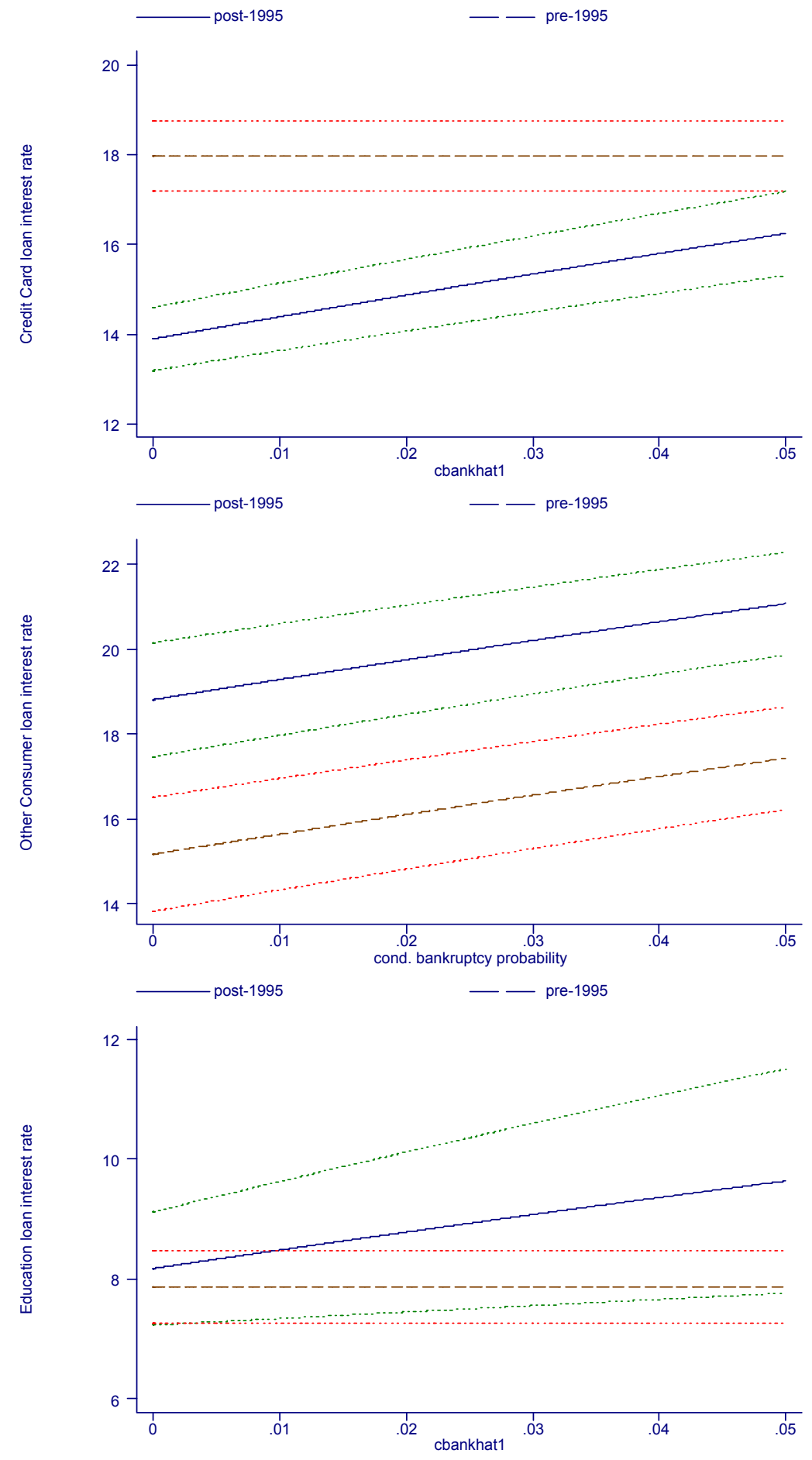


\section{Figure 2.Predicted Debt Holdings by Bankruptcy Risk}
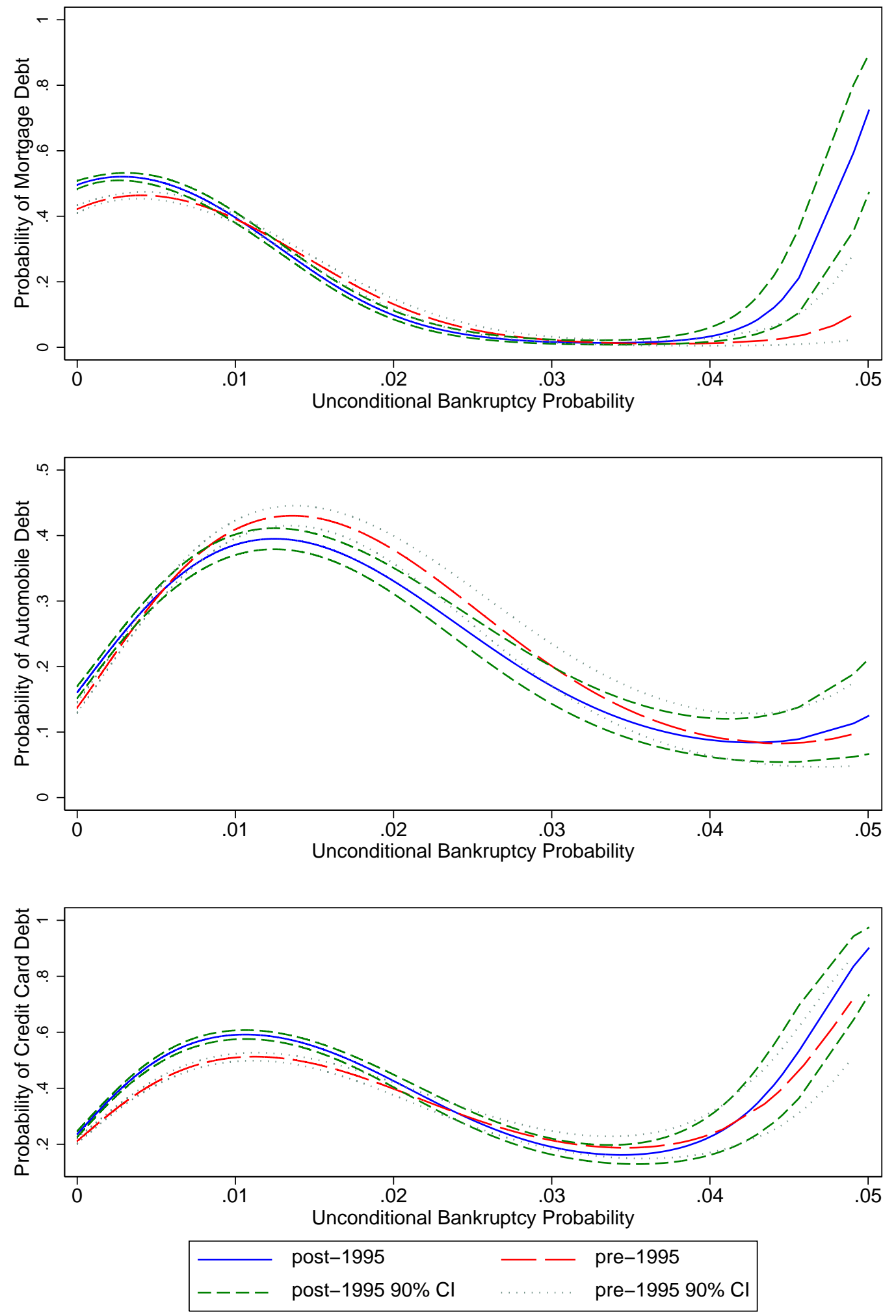
Figure 2. continued
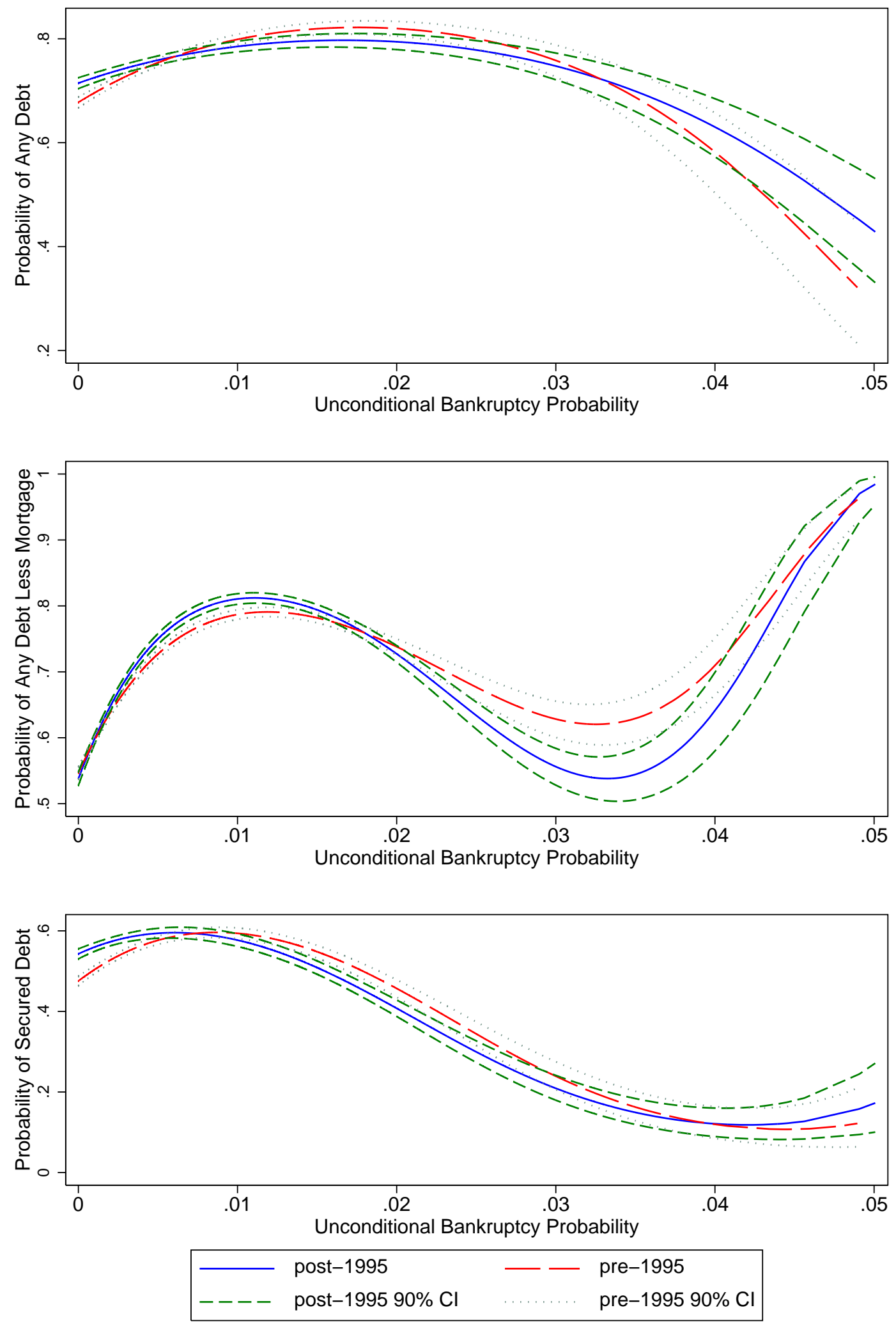


\section{Figure 2. continued}
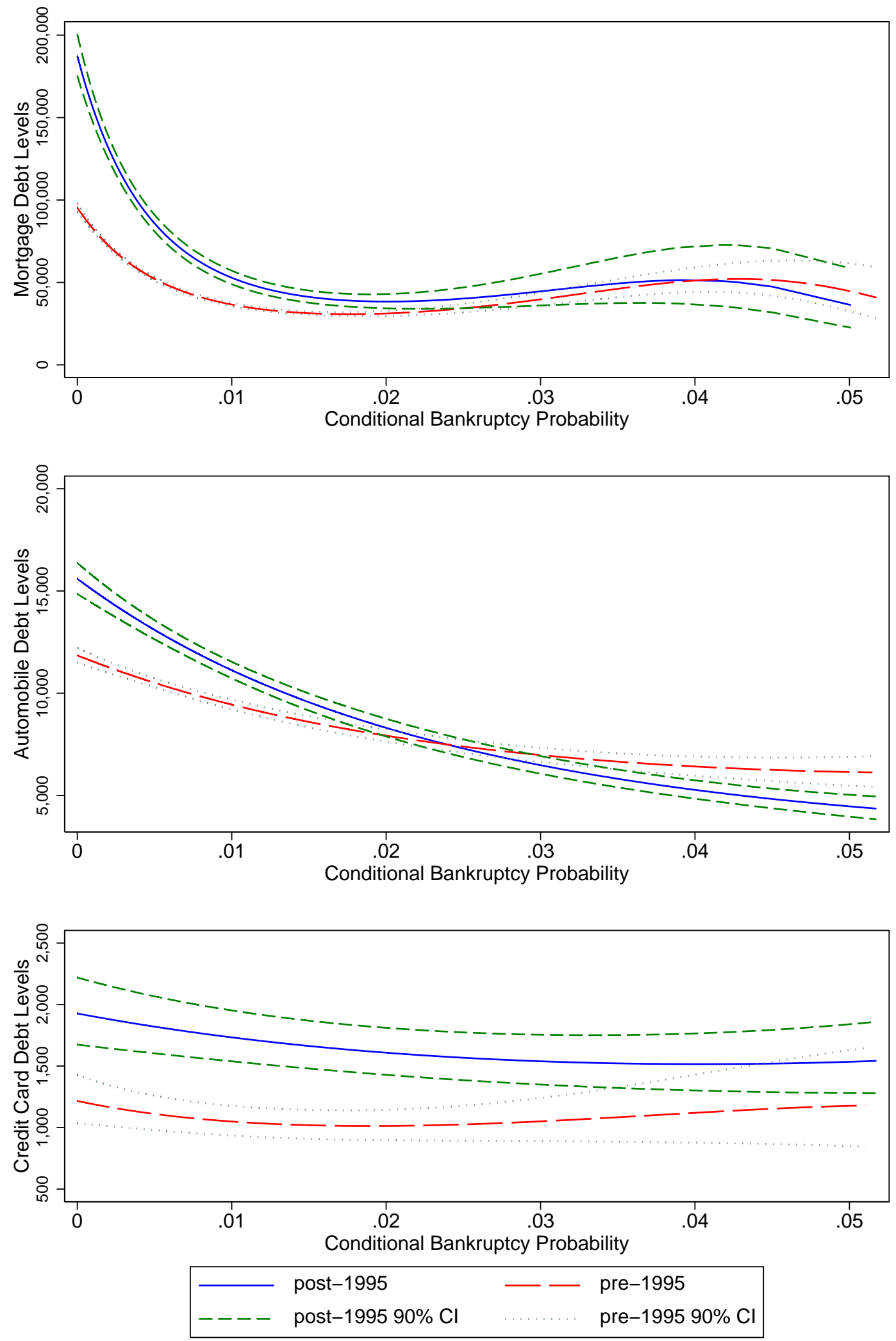
Figure 2. continued
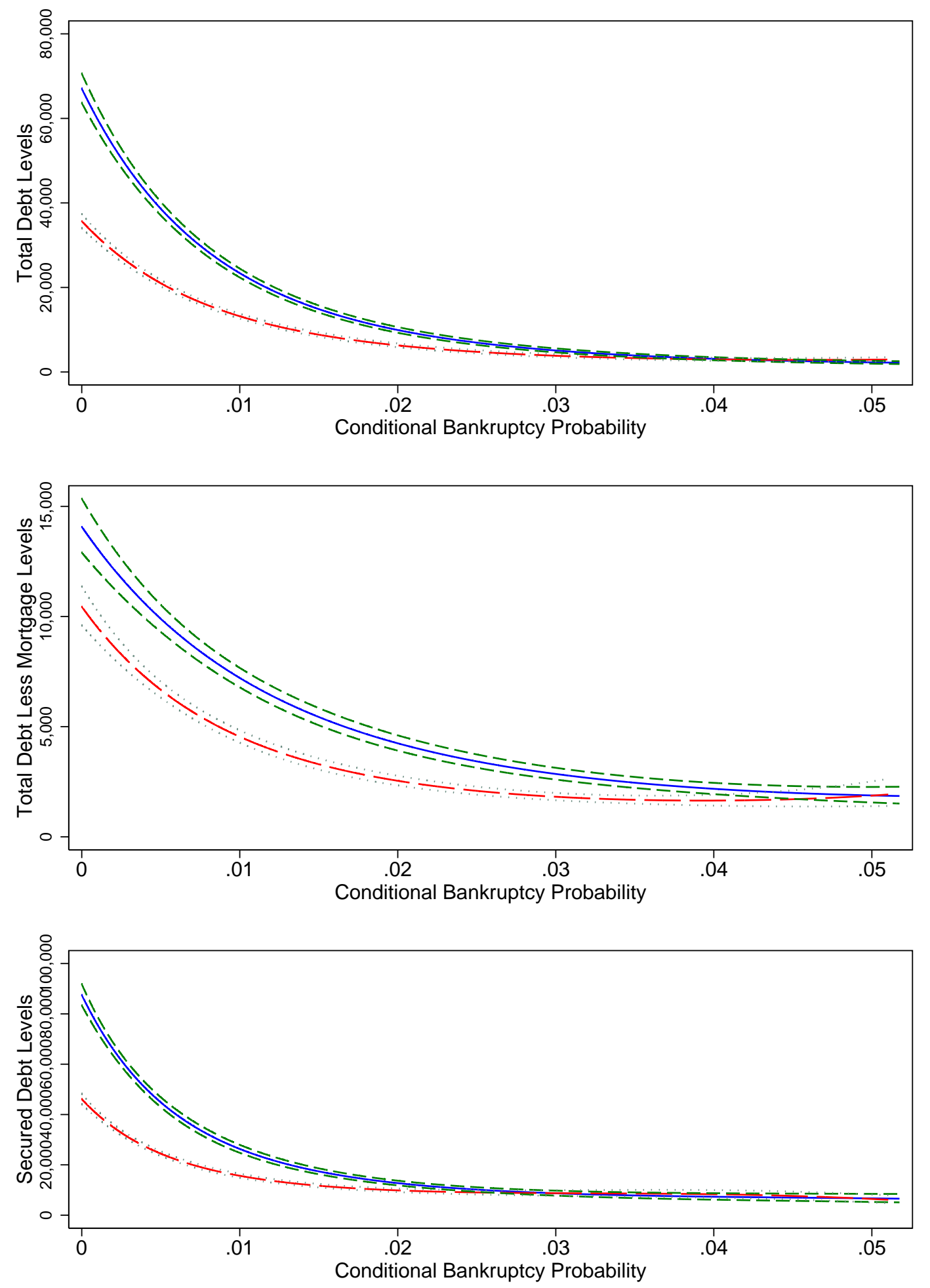

\begin{tabular}{llll|}
\hline- & post -1995 & - & pre-1995 \\
---- & post $-199590 \% \mathrm{Cl}$ & $\ldots \ldots \ldots$ & pre-1995 $90 \% \mathrm{Cl}$ \\
\hline
\end{tabular}




\section{Figure 3. Estimated Effects of Risk-Based Pricing}
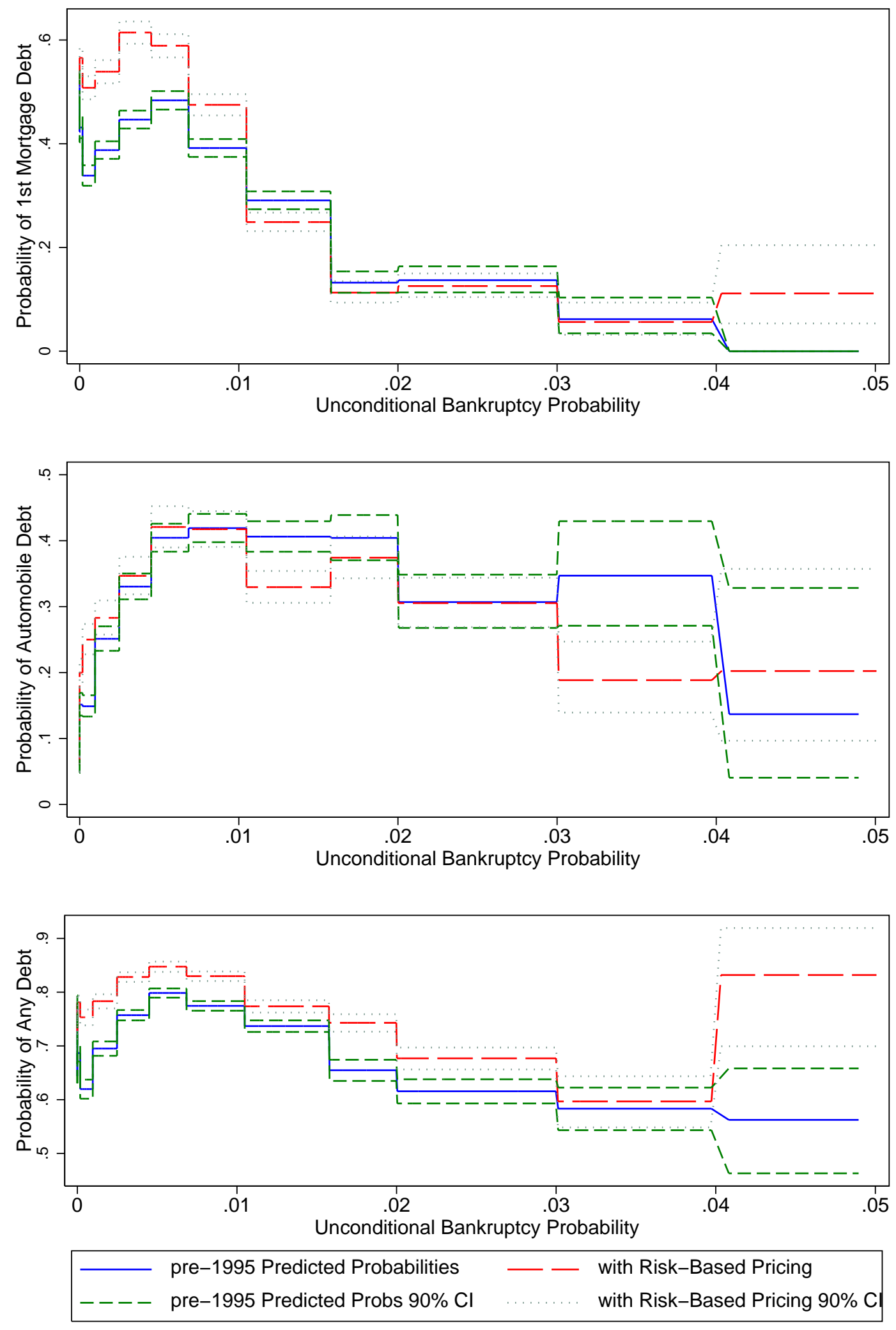
Figure 3. continued
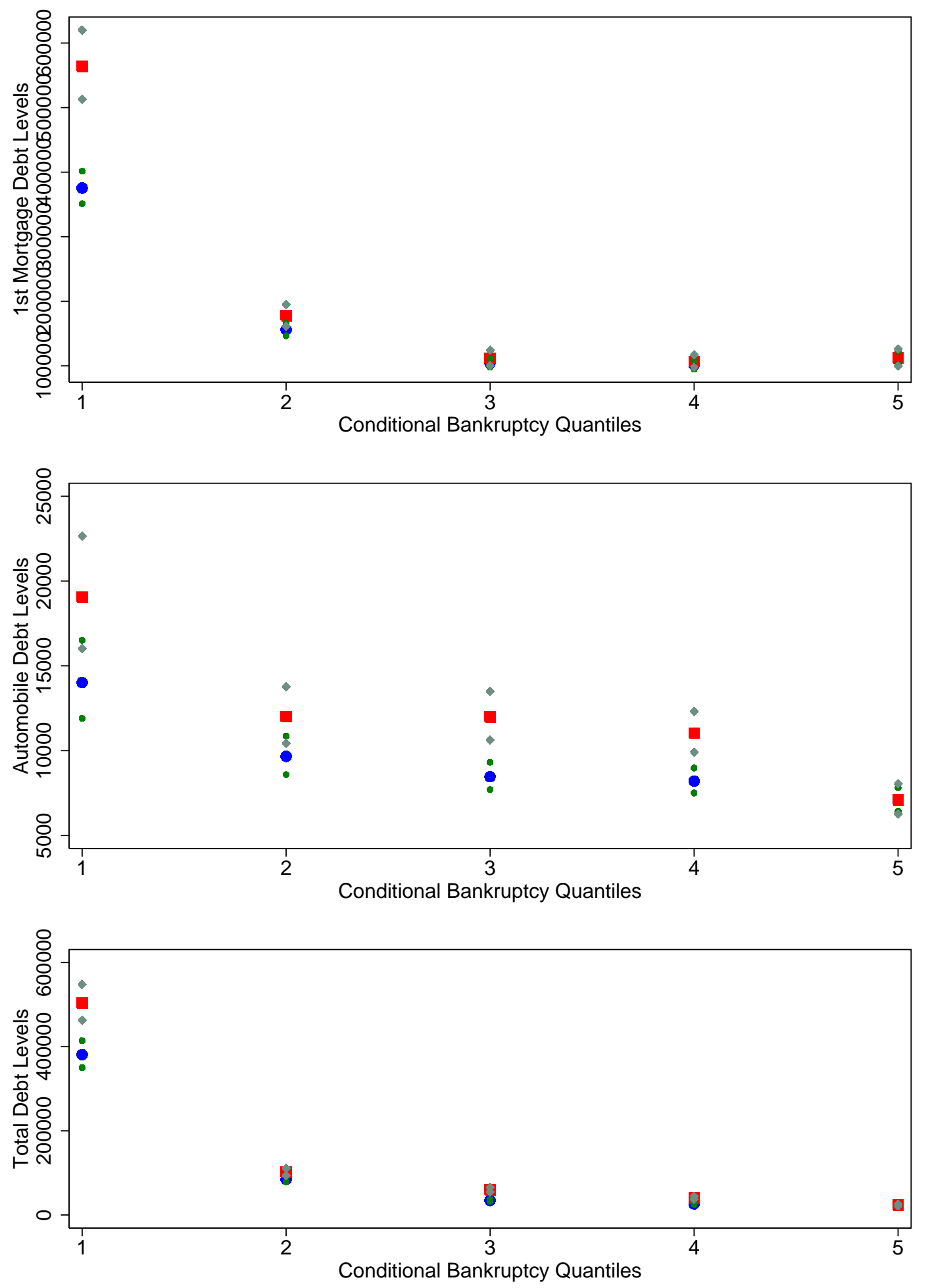

\begin{tabular}{|ll|}
\hline - pre-1995 Predicted Probabilities & - with Risk-Based Pricing \\
- pre-1995 Predicted Probs $90 \% \mathrm{Cl}$ & - with Risk-Based Pricing $90 \% \mathrm{Cl}$ \\
\hline
\end{tabular}

